\title{
ANTICORPOS MONOCLONAIS E POLICLONAIS PARA IDENTIFICAÇÃO DO TOBAMOVÍRUS DO MOSAICO DO TOMATEIRO (TOMV) EM PLANTAS DE TOMATE (Lycopersicon esculentum Mill.)
}

\section{KEILA MARLA RONCATO DUARTE}

Enga. Agrônoma, Mestre em Agronomia

Orientador: Prof. Dr. Flavio Cesar Almeida Tavares

Tese apresentada à Escola Superior de Agricultura "Luiz de Queiroz", da Universidade de São Paulo, para obtenção do título de Doutor em Agronomia. Área de Concentração: Microbiologia Agrícola.

Piracicaba, Janeiro de 2000. 
Dados Internacionais de Catalogação na Publicação (CIP)

DIVISÃO DE BIBLIOTECA E DOCUMENTAÇÃO - Campus ‘Luiz de Queiroz”/USP

Duarte, Keila Maria Roncato

Anticorpos monoclonais e policlonais para identificação do tobamovírus do mosaico do tomateiro (ToMV) em plantas de tomate (Lycopersicon esculentum Mill.) / Keila Maria Roncato Duarte. - - Piracicaba, 2000.

87p. : il.

Tese (doutorado) - Escola Superior de Agricultura Luiz de Queiroz, 2000. Bibliografia.

1. Anticorpo 2. Identificação microbiana 3. Mosaico-do-tomateiro 4. Planta indicadora

5. Técnica imunoenzimática 6. Tobamovírus 7. Vírus patogênico

CDD 635.642

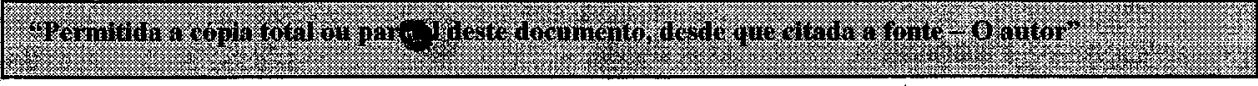




\section{AGRADECIMENTOS}

Ao Prof. Dr. Flavio Cesar Almeida Tavares, pela Orientação e o carinho;

À FAPESP, pelo apoio financeiro sem o qual não seria possivel a realização deste trabalho;

Aos Doutores José Daniel Lopes, Jean-Luc Gesztesi, Jane Z de Moraes e Célia W. Carneiro (UNIFESP/SP) pela sempre presente orientação na área de Imunologia e amizade n estes anos;

Aos Professores Dr. Jorge A. M. Rezende (ESALQ/USP) e Dr. Marcelo Pavan (UNESP/Botucatu) pelas sementes, vírus e pela orientação na área da Virologia Vegetal;

Ao Decano, Professor Dr. Luiz Gonzaga do Prado Filho, pelos conselhos, pela convivência, pelo bom humor e pela inestimável amizade;

Ao meu querido Luiz Humberto Gomes, pela extrema paciência na hora de ensinar, pelo apoio e companheirismo sempre presentes e sobretudo pelo amor que cultivamos;

A Ana Carolina, por me mostrar sempre o lado bom da vida;

A meus Pais e irmãos, que representam uma fortaleza em minha vida sempre de portas abertas $e$ que me deram educação e liberdade para que eu escolhesse a minha carreira;

Aos queridos Ana Maria B. Giacomelli, Felipe Gabriel Andrino, Gildemberg A. Leal Jr., Fabio Henrique B. da Silva, Jonas Augusto R. Paschoal, Elaine Cristina Castelhano, Maurício P. M. Barbosa, Janaina Rodrigues, Jefferson W. de Gaspari e Fernanda Garutti po raturarem meu mau humor e tornarem o ambiente de trabalho uma verdadeira reunião de amigos;

$\grave{A}$ amiga Olga Satie Suzuki, que sempre acreditou em mim;

A todos os funcionários do Departamento de Genética que me ajudaram nestes anos todos, em especial ao Fernando, Sarah, Oberdan, Silvana, Neuza, Gorga, Adriana e Valdir. 


\section{Indice}

Página

LISTA DE FIGURAS......................................................................

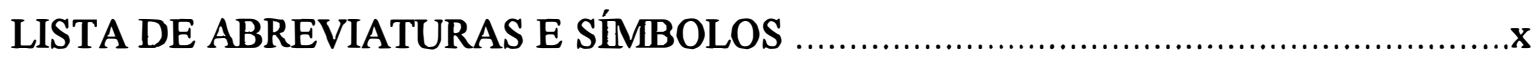

RESUMO

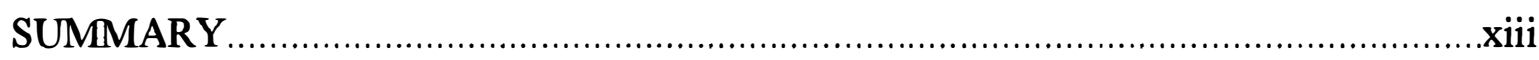

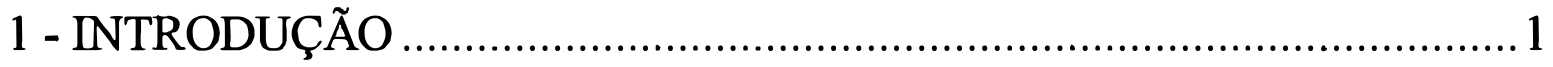

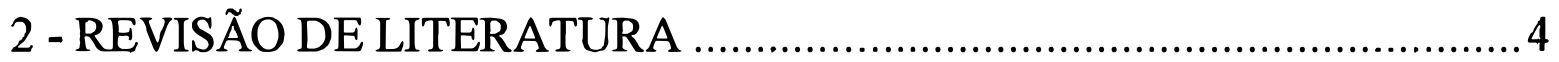

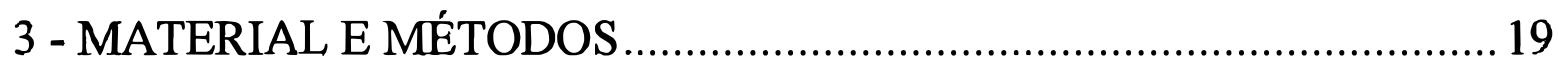

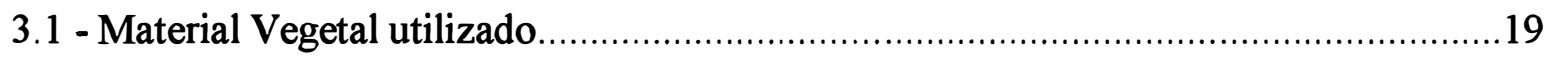

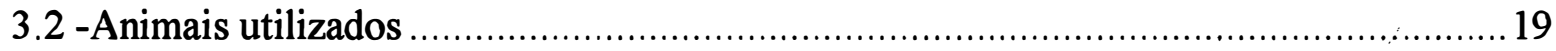

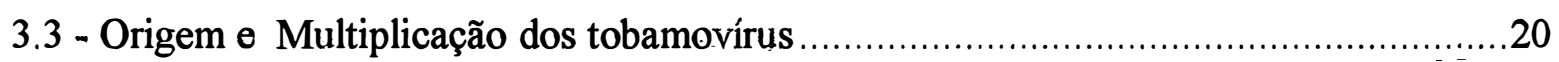

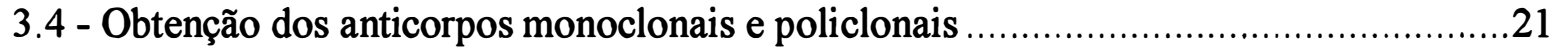

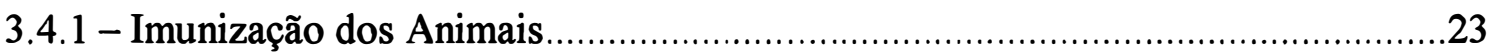

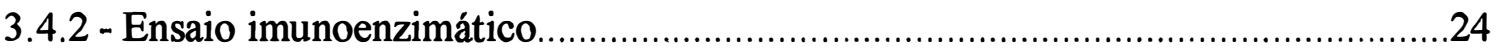

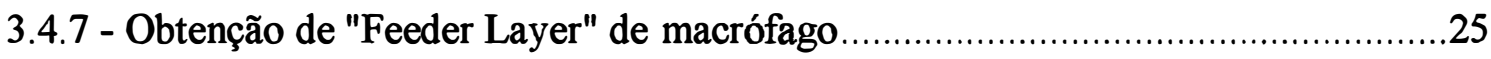

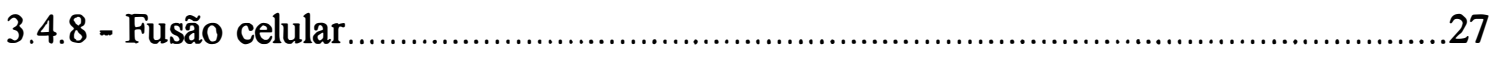

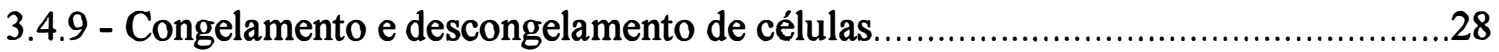

3.4.10 - Clonagem e Reclonagem dos melhores híbridos ...........................................28

3.5 - Coleta do material no Campo

3.6 - Caracterização dos anticorpos monoclonais e policlonais............................................36

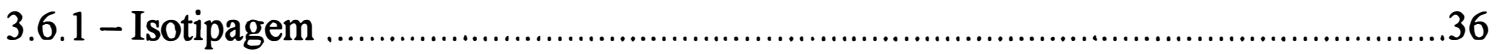

3.6.2 - Purificação em Coluna de Proteína A ( Oi \& Herzenberg, 1980)...........................36 
3.6.3-Ensaio de competição

3.6.4 - Ensaio de Reatividade do ToMV e Utilização do Tampão de Bloqueio ao longo

do tempo

3.6.5 - Ensaio com plantas infectadas

3.6.6 - Teste com as amostras coletadas.

3.6.7 - Teste biológico com plantas de tomate e de tabaco 39

3.6.8 - Eletroforese de proteínas Totais (SDS-PAGE) 39

3.6.9 - Imuno Blot (Harlow \& Lane, 1988). .40

3.6.9.1 - Protocolo 1 40

3.6.9.2 - Protocolo 2

3.7 - Soluções utilizadas.

3.8 - Meios de Cultura utilizados.

4 - RESULTADOS E DISCUSSÃO

4.1 - Obtenção dos anticorpos monoclonais e policlonais .49

4.2 - Caracterização dos anticorpos monoclonais e policlonais produzidos. .52

4.2.1 - Isotipagem. 52

4.2.2 - Resultado da Purificação dos tobamovírus TMV e ToMV 52

4.2.3 - Ensaio de Competição

4.2.4 - Ensaio de Reatividade do ToMV e Utilização do Tampão de Bloqueio ao longo do tempo

4.2.5 - Ensaio com Plantas Infectadas 56

4.2.6 -Ensaio com as Amostras Coletadas. . 57

4.2.7 - Resultados do Teste Biológico em plantas de tomate e de tabaco 57 
4.2.8 - Eletroforese de proteínas totais - SDS-PAGE .........................................61

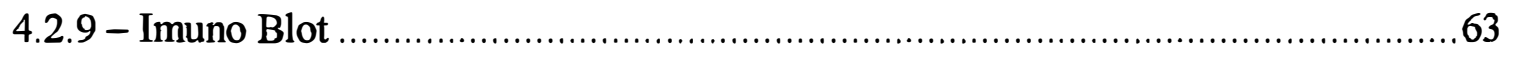

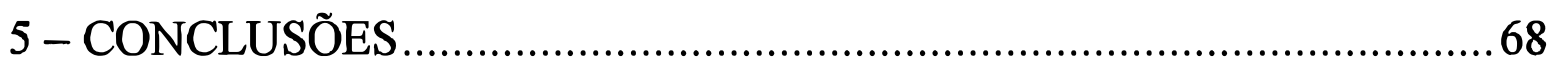

6 - BIBLIOGRAFIA CITADA.................................................... 70 


\section{LISTA DE FIGURAS}

Figura 1 - Esquema de produção de anticorpos monoclonais segundo Campbell (1984) adaptado por Duarte (1996)

Figura 2 - Esquema da cavidade peritoneal de um camundongo de onde são retirados os macrófagos (Duarte,1996). .26

Figura 3 - Mapas mostrando a região do Brasil referente aos municípios mencionados e, no plano mais detalhado circundado em preto, as cidades de Conchal, local de aparecimento do ToMV do país, Aguaí e Mogi-Guaçu, regiões produtoras de tomate 32

Figura 4 - Planta e frutos de tomate var. Santa Clara exibindo sintomas de ToMV, como manchas nos folíolos e nos frutos. 33

Figura 5 - Plantas de tomate var. Santa Clara com sintomas do ToMV (acima) e do complexo do "vira-cabeça" (abaixo). 
Figura 6 - Planta de tomate, var. Santa Clara, no campo exibindo início dos sintomas de infecção por ToMV (mosaico e enrugamento dos folíolos).

Figura 7 - Titulação dos camundongos imunizados a intervalos de 20 dias, onde foram coletados os soros 1,2,3 e 4 respectivamente. Cada curva representa resultados do ELISA realizado com soro na diluição de 1:200 dos quatro animais e do camundongo normal, usado como controle. .50

Figura 8 - Resultados da titulação dos anticorpos monoclonais selecionados contra o ToMV, utilizando 100 ul de de sobrenadante de cultura, em ensaio do tipo ELISA indireto utilizando o TMV e o ToMV como antígenos

Figura 9 -Ensaio de ELISA, mostrando competição do anticorpo monoclonal 10.H1(ascite) e soro policlonal de coelho, ambos contra ToMV

Figura 10- Gráfico de reatividade do ToMV em testes de ELISA ao longo do tempo, com e sem tampão de bloqueio .55

Figura 11 - Ensaio utilizando plantas infectadas com TMV, plantas infectadas com ToMV e planta sadia em ELISA 
com ascite do MAb 10.H1 na concentração de $50 \mathrm{ug} / \mathrm{ml}$ de

IgG, onde os extratos de plantas foram diluídos em PBS

100 vezes, 200 vezes e 500 vezes

Figura 12 - ELISA de amostras retiradas do campo conTendo sintomas de ToMV , comparado com plantas sadias, plantas com sintomas de TMV e do complexo Vira-cabeça. As amostras foram maceradas e diluídas 100 vezes em PBS. 57

Figura 13 - Sintomas severos do ToMV em planta de tomate var.Santa Clara (a esquerda), em comparação com a planta sadia (a direita). .58

Figura 14 - Sintoma típico de afilamento e deformação dos folíolos do tomateiro causada pela inoculação do ToMV. $\mathrm{Na}$ foto, todos os folíolos apresentam-se deformados. 59

Figura 15 - Folha de tabaco (N. rustica) exibindo sintomas locais devido à inoculação com ToMV (folha de cima), comparado com folha sadia (folha que está abaixo) 60

Figura 16 - Gel de SDS-PAGE corado com Prata onde se vê, da esquerda para a direita: P -padrão de peso molecular, 
1 - ToMV macerado uma vez; 2 - ToMV macerado duas vezes; 3 - Fruto de tomate infectado com ToMV; 4 - Planta de tomate infectada com ToMV; 5 - Planta de tabaco infectada com ToMV e 6 - Planta de tabaco sadia. 62

Figura 17 - Gel de eletroforese de proteínas totais corado com prata onde temos o padrão de peso molecular em $\mathrm{kDa}$, canaleta 1: plantas de tomate com ToMV; 2: planta de tomate sadia; 3: planta de tabaco com ToMV; 4: planta de tabaco sadia 64

Figura 18 - Immunobloting mostrando as duas bandas reconhecidas pelo anticorpo policlonal produzido em coelho, contra o ToMV, nas plantas de tomate infectado (primeira canaleta da esquerda para direita) e em fumo infectado (terceira canaleta, também da esquerda para a direita). Esta membrana de nitrocelulose foi revelada com NBT/BCIP

Figura 19 - Immunobloting utilizando o Mab 10.H1, revelado com 4-cloronaftol, onde vemos apenas uma banda referente à capa proteica do ToMV. 


\section{LISTA DE ABREVIATURAS E SÍMBOLOS}

ToMV - tobamovírus do mosaico do tomateiro

TMV - tobamovírus do mosaico do tabaco

$\mathrm{MAb}$ - anticorpo monoclonal

${ }^{0} \mathrm{C}$ - graus Celsius

ELISA - ensaio imuno-enzimático ("enzyme-linked immunosorbent assay")

PTA-ELISA- ensaio imuno-enzimático do tipo "Plate trapped antigen"

PCR - "polimorphic chain reaction"

RT-PCR - PCR de transcrição reversa

DAS-ELISA - duplo sanduíche de ELISA

TAS-ELISA - sanduíche triplo de ELISA

M , mM - molar, mili molar

pH - cologarítimo de concentração hidrogeniônica

$\mathrm{g}, \mathrm{mg}, \mu \mathrm{g}$ - grama, miligrama, micrograma

h, min. - hora, minuto

$\mathrm{g}, \mathrm{rpm}$ - força centrípeta, rotações por minuto

$\mathrm{L}, \mathrm{ml}$ - litro, mililitro

IgG - imunoglobulina do tipo $\mathrm{G}$

$\mathrm{nm}$ - nanômetro

D.O. - densidade ótica

$\mathrm{cm}^{2}$ - centímetro quadrado

PBS - solução tampão de fosfato

BSA - soro albumina bovina

SDS-PAGE - eletroforese de gel de poliacrilamida com dodecil sulfato de sódio

$\mathrm{SBF}$ - soro fetal bovino

HAT , HT - hipoxantina-aminopterina-timidina, hipoxantina-timidina

DMSO - dimetil sulfoxido

KDA - kilo Daltons 
ANTICORPOS MONOCLONAIS E POLICLONAIS PARA IDENTIFICAÇÃO

DO TOBAMOVÍRUS DO MOSAICO DO TOMATEIRO (TOMV) EM

PLANTAS DE TOMATE (Lycopersicon esculentum Mill.)

\author{
Autora: Keila Maria Roncato Duarte \\ Orientador: Prof. Dr. Flavio Cesar Almeida Tavares
}

\title{
RESUMO
}

O tomateiro (Lycopersicon esculentum Mill.) é uma olerícola de grande importância econômica e uma das mais suscetíveis a viroses, dentre as quais, o tobamovírus do mosaico do tomateiro (ToMV), que causa mosaicos verde claro-escuro nas folhas, afilamento de folíolos, diminuição da produção, entre outros sintomas. Visando a identificação precoce do ToMV, foram produzidos anticorpos monoclonais (MAbs) e anticorpos policlonais. Dentre os MAbs produzidos, escolheu-se aquele que apresentou melhor título em PTA- ELISA ("plate trapped antigen- enzyme linked immunoassay") sem reação cruzada com tobamovírus do mosaico do tabaco (TMV) e com proteínas do extrato da planta. Este MAb (10.H1), juntamente com os anticorpos policlonais, foram utilizados para avaliar a capacidade de identificação do ToMV em testes de campo com palntas de tomate infectadas. Destas plantas foi isolado o ToMV, que foi purificado e re-inoculado em plantas de tomateiro e de tabaco, para confirmação dos sintomas. Em imuno blot os anticorpos policlonais permitiram reconhecer duas bandas protéicas (de 17,5 kDA e de $30 \mathrm{kDa}$ ) enquanto que o MAb 10.H1 reconheceu 
somente a proteína referente à capa protéica do ToMV (de 17,5 kDa). A maior especificidade do MAb 10.H1 pode permitir o diagnóstico precoce desta doença na fase de plântulas, ainda em casa de vegetação, evitando assim a disseminação desta virose no campo. 


\title{
MONOCLONAL AND POLYCLONAL ANTIBODIES TO \\ IDENTIFY TOMATO MOSAIC TOBAMOVIRUS (TOMV) IN \\ TOMATO PLANTS (Lycopersicum esculentum MILL.)
}

\author{
Author: Keila Maria Roncato Duarte \\ Adviser: Prof. Dr. Flavio Cesar Almeida Tavares
}

\section{SUMMARY}

The tomato crops are one of the most important vegetables for the world economy and it is very susceptible to virus diseases, among them the tomato mosaic tobamovirus (ToMV) that causes light and dark green mosaic in the leaves, decreases the production, among other symptoms. With the aim to early identify ToMV in biological material, harvested from crop fields, monoclonal antibodies (MAbs) and polyclonal antibodies were produced against ToMV. The MAb $10 . \mathrm{H1}$ was chosen by PTA-ELISA (Plate Trapped Antigen -Enzyme-Linked immunoassay) and do not crossreact with TMV (tobacco mosaic tobamovirus) or with proteins extracted from plant sap. The MAb and the polyclonal antibodies produced were able to identify ToMV from infected plants collected in field. These plants were used to isolate the virus, which were purified and used to re-inoculate tobacco and tomato plants to confirm the symptoms. In immunoblots assays the polyclonal antibodies recognize two protein 
bands (17.5 $\mathrm{kDA}$ and the $30 \mathrm{kDa}$ bands) and the MAb recognizes only the band corresponding to the coat protein of the ToMV $(17.5 \mathrm{kDa})$. The MAb 10.H1 opens the possibility to identify ToMV in tomato seedlings avoiding its dissemination in the crop fields. 


\section{1 - INTRODUÇÃO}

O tomateiro é suscetível a mais de 40 viroses que ocorrem no mundo e, embora o tobamovírus do mosaico do tomateiro (ToMV) não seja a virose mais importante no Brasil, vem acarretando prejuízos crescentes às do Estado de São Paulo, devido a variedade de mesa mais cultivada a "Santa Clara", apresentar alta suscetibilidade a esse vírus, que é transmitido via sementes (Bastos, 1998). Desta forma programas de melhoramento aliados a testes precisos de diagnóstico precoce tem assumido uma importância cada vez maior (Jones et al., 1991).

Considerando o custo de produção da cultura do tomate aliado ao fato do tomate estar entre os dez primeiros produtos da agricultura brasileira (Melo, 1996). Com uma produção neste ano de 1999 de 3,1 milhões de toneladas de tomate para mesa e para indústria em cerca de 65 mil hectares (Agrianual 2000), o Brasil ficou posicionado como nono produtor mundial de tomate, e o Estado de São Paulo como principal produtor. $\mathbf{O}$ grande aumento do consumo nos últimos quatro anos devido ao consumo de enlatados e alimentos processados que utilizam polpa de tomate havendo assim a necessidade de importação de polpa, principalmente em países como o Chile e EUA, as inúmeras possibilidades de aplicação da tecnologia de produção de anticorpos monoclonais neste 
setor, pode auxiliar não só no diagnóstico do ToMV em sementes e plântulas mas também em diversas várias fases do processo produtivo, inclusive na estocagem e comercialização de produtos, contribuindo para melhorar a eficiência de outras tecnologias. $\mathrm{O}$ uso de anticorpos monoclonais tem possibilitado conhecer vários processos biológiços de importância para a Agricultura. Existem vários exemplos de aplicações práticas, principalmente no diagnóstico de doenças e de marcas genéticas relacionadas à produção ou expressão de proteínas. Muitos anticorpos são comercializados atualmente na forma de "kits" para determinações rápidas e precisas. Apesar das vantagens desta tecnologia, sua aplicação ainda é bastante pequena na área vegetal quando comparada à área veterinária e médica . Tem-se recorrido à métodos baseados em sorologia no estudo de fitopatógenos de dificil identificação, seja porque a sintomatologia não oferece a precisão desejada ou porque não há evidência de sintomas nas fases iniciais do desenvolvimento da cultura. Neste sentido, é inquestionável o valor de metodologias, que permitam o diagnóstico precoce, que pode portanto significar tanto a garantia de lucros como evitar perdas decorrentes da infestação assintomática nas culturas ou dos produtos agrícolas.

Devido a sua alta especificidade, anticorpos tem sido utilizados para purificar, classificar, identificar e quantificar substâncias de interesse biológico (Trione, 1988). A sorologia baseada em anticorpos policlonais oferece anticorpos que variam na quantidade e qualidade, dependendo do animal que os produziu e a utilização de anticorpos monoclonais (Köhler \& Milstein, 1975) por outro lado, embora envolva maiores custos e mão-de-obra especializada, apresenta vantagens em relação aos anticorpos policlonais, como a obtenção de grandes quantidades de anticorpos altamente específicos em relação ao 
antígeno. A tecnologia atualmente torna possível produzir tais anticorpos em escala industrial, com recursos de preservação adequados para viabilizar seu uso econômico.

Desde que células produtoras destes anticorpos podem ser mantidas como clones idênticōs, passam a constituir em fonte inesgotável de reagentes altamente sensíveis e específicos: A especificidade dos anticorpos monoclonais produzidos contra o ToMV, durante o trabalho de mestrado não foi alcançada, uma vez que a tecnologia ainda não havia sido otimizadà para os vírus vegetais.

Como conseqüência de que a presença de fitopatógenos obedece a particularidades regionais e da cultura em questão, como é o caso do ToMV, este trabalho teve como objetivos produzir anticorpos monoclonais e policlonais de maior especificidade; utilizar estes anticorpos em plantas de tomate (Lycopersicon esculentum Mill.) infectadas com ToMV, testando assim a efetividade dos anticorpos produzidos; avaliar os anticorpos policlonais visando especificidade e custos e, avaliar o nível de reação cruzada para o TMV e para os extratos vegetais. 


\section{2 - REVISÃO DE LITERATURA}

A cultura do tomate (Lycopersicon esculentum Mill.) no Brasil é a mais importante do ponto de vista sócio-econômico pois é uma das culturas mais dificeis de se conduzir pois requer numerosos tratos culturais, é susceptível a numerosas doenças, aspectos que encarecem muito a produção, além dos frutos serem altamente perecíveis (Espinoza, 1991). O Estado de São Paulo produziu, em 1999 cerca de 767.580 toneladas, em 14.030 ha, sendo o principal produtor no país, responsável por quase um terço do tomate produzido (Agrianual, 2000).

O tomateiro é suscetível a aproximadamente quarenta (40) viroses (Jones et al., 1991) dentre cerca de 200 doenças e a ocorrência do tobamovírus do mosaico do tomateiro (ToMV) em tomateiros no Estado de São Paulo é da maior importância, pois a disseminação do vírus pode se dar por contato de folhas, operações culturais, e, principalmente, através de sementes, onde o vírus se localiza na mucilagem externa e, algumas vezes, no endosperma (Hollings \& Huttinga, 1976). O ToMV pode ainda infectar plantas de pimentão, pepino e outras Solanáceas destinadas ao o consumo de mesa. Desta 
forma faz-se necessário um teste capaz de diagnosticá-lo antes do plantio das sementes ou no transplante.

O ToMV foi pela primeira vez observado em plantas de tomate (Lycopersicon esculentum Mill.) em 1909, em Connecticut/USA e teve seu primeiro relato no Brasil feito por Nagai e Costa (1972) com perdas de cerca de 70\% nos campos atacados e também mais tarde, em duas regiões produtoras de tomate, localizadas na Zona da Mata e no Triângulo Mineiro, no estado de Minas Gerais, sendo constatada sua ocorrência em 73\% das amostras (Fernandes et al., 1983). Contudo o ToMV foi identificado e çaracterizado apenas em 1990, no município de Conchal, SP (Carner et al., 1990).

O ToMV tem potencial de se tornar um vírus economicamente importante no país, pois resulta em grandes perdas na produção de tomates, especificamente na Europa (Jones et al., 1991). Os sintomas no tomateiro são mosaicos de áreas verde claro e escuro nas folhas; o enrolamento, a redução e afilamento de folíolos, além de apresentar aspecto bolhoso nas folhas e aspermia de frutos.

Como características gerais do ToMV, este vírus faz parte do gênero dos Tobamovírus; contém RNA de fita simples como material genético; possui tamanho de 300 por $18 \mathrm{~nm}$, sua partícula intacta é altamente estável, possuindo ponto de inativação térmica de $90{ }^{0} \mathrm{C}$ representando um dos vírus mais persistentes e infecciosos de que se tem conhecimento. Sua transmissão pode se dar através de ferramentas e pelo manuseio humano, assim como por sementes, o que o torna mais problemático que o TMV, cuja transmissão não se dá através de sementes (Zaitilin e Israel, 1975). O vírus pode permanecer ativo por anos, sendo bastante sensível à umidade do solo (em solos secos, 
chega a permanecer latente por dois anos e em solos úmidos, por apenas um mês), tendo-se o cuidado de eliminar os restos culturais de forma a não serem fonte de inóculo para o solo.

A ocorrência de insetos vetores na transmissão desses vírus ainda é desconhecida, mas sua transmissão via solo, e na água coletada das chuvas, ou seja, transmitido pelas nuvens e neblina já foram relatadas (Castello et al., 1995 e Fillart \& Castello, 1996). O vírus pode permanecer também no fluido de gutação de plantas infectadas, sendo possível sua transmissão mecânica para plantas sadias (French et al., 1993).

A transmissão de ToMV e do tobamovírus do mosaico do tabaco (TMV) através do solo tem sido objeto de estudo de diversos grupos, pois torna-se relevante o fato de viveiros de mudas estarem utilizando solos infectados para o cultivo de tomate. Estudos realizados por Fillart et al. (1998) relataram que dos solos utilizados em casas de vegetação para o cultivo de hortaliças, $38 \%$ das amostras apresentaram contaminação por ToMV e TMV.

Apesar do ToMV causar prejuízos para o tomateiro, existe uma gama bastante grande de hospedeiros intermediários, nos quais ele se aloja, sendo mais comuns as plantas das famílias das Aizoaceae, Amaranthaceae, Chenopodiaceae, Scrophulariaceae e Solanaceae. Em Cuba, foi relatada a ocorrência de ToMV em plantas de Catharanthus roseus, uma planta ornamental da família das Amaranthaceae, em 1992 (Alonso e Mejias, 1992). Em plantações de abeto vermelho (Picea rubens) para madeira, tobamovírus foram detectados em $100 \%$ das amostras de raízes em plantações em Syracuse, NY (USA). Um monitoramento da doença está sendo feito através de ELISA usando anticorpos policlonais em intervalos de 15 dias (Bachand \& Castello, 1998). O ToMV tem se tornado uma 
importante doença em cultivos hidropônicos de tomate e pimentão, onde há um alastramento muito rápido da doença e prejuízos econômicos para os produtores (Schuerger \& Brown, 1997).

No Brasil, o controle dessa virose resume-se no uso de sementes sadias, fuga de áreas contaminadas, rotação de cultura, e, finalmente, um manejo adequado ao plantio de qualquer cultura. Bos (1983) cita o tratamento térmico para sementes secas de tomate, utilizando ar quente a $70-76{ }^{\circ} \mathrm{C}$ por 1 a 3 dias, embora este método nã் erradique o vírus do embrião da semente e, para realizá-lo, mataria o embrião e inviabilizaria as sementes. Na Europa, faz-se menção do tratamento de sementes utilizando uma solução de fosfato trissódico $\left(\mathrm{NA}_{3} \mathrm{PO}_{4}\right)$ a $10 \%$ por pelo menos 15 minutos ou então o tratamento térmico para sementes secas, contudo estes tratamentos ainda estão em fase de experimentos (Jones et al., 1991).

A caracterização do ToMV, distinguindo-o do TMV pode ser feita baseada em reações sorológicas, seqüência de aminoácidos constituintes da capa protéica ou por plantas hospedeiras diferenciadoras de ambos os tobamovírus, como Nicotiana rustica, $N$. sylvestris, N. tabacum "White Burley" (linha necrótica), Petunia hibrida, P. nyctagyniflora, Physalis ixocarpa e Solamum giganteum, que apresentam lesões locais quando inoculadas com ToMV e lesões sistêmicas, quando inoculadas com TMV (Rast, 1975).

Entre os problemas encontrados no uso de plantas indicadoras, além das instalações apropriadas, necessita-se ter o vírus purificado para a realização do teste e dispor de tempo, desde a produção das mudas da planta indicadora, até a visualização dos sintomas após a inoculação dos vírus, sem contar com a existência de uma estirpe do TMV que também causa lesão local. Este fato, quando se trata de estabelecer a sanidade de um 
lote de sementes ou o diagnóstico da doença já instalada no campo, torna-se inviável. Pelo menos duas estirpes do ToMV já foram relatadas (Bastos, 1998) o que reforça a necessidade de se ter um teste eficiente para o diagnóstico desta doença no país.

A diferenciação das estirpes do ToMV para fins de melhoramento genético foi determinada por Pelham (1972) e posteriormente por Rast (1975). No estado de São Paulo, a caracterização de estirpes em plantações foi realizada por Bastos (1998) onde das cinco estirpes relatadas na literatura, apenas duas foram encontradas - a estirpe tm- 0 e tm-1 sendo que a tm-1 foi predominante neste Estado.

O diagnóstico de doenças exige em muitas situações, além da análise de sintomas, o emprego de outros recursos para a identificação precisa do agente causal, principalmente quando se trata de vírus. $\mathrm{O}$ conhecimento adequado de uma virose exige recursos especializados e a aplicação de várias metodologias que permitam sua identificação e caracterização, inclusive de seus variantes genéticos ou estirpes, hospedeiros e sintomas. Raramente se dispõe de todos os meios para este fim, mas ao se trabalhar com uma virose convém isolar o agente causal e diferenciá-lo de outros patógenos que causem confusão (Bergamin et al., 1995). Estes aspectos freqüentemente dificultam o estudo demandando tempo e recursos de infra-estrutura especializados. A nível de campo, a precisão com que são feitos os diagnósticos dependerá de sintomas bastante característicos, o que nem sempre ocorre de forma isolada (Sequeira, 1992).

Estudos imunoquímicos sobre os tobamovírus tem sido feitos desde a década de 70. Trabalhos pioneiros como os de Van Regenmortel \& Lelarge (1973), já demonstravam a especificidade antigênica das proteínas do TMV, realizada em ensaios de imunodifusão, imunoeletroforese e outros testes de precipitação. Um pouco mais tarde, 
foram relatadas as sub-unidades da proteína do TMV (Milton \& Van Regenmortel, 1979), e também a localização de quatro epitopos em sub-unidades específicas, através de testes de inibição com pepitídeos sintéticos de três linhagens de TMV (Altschuh et al., 1984).

Uma vez que a metodologia de isolamento dos tobamovírus já é bastante conhecida, faz-se necessário desenvolver um teste bastante sensível capaz de diagnosticar quantidades mínimas do vírus e separar outros vírus semelhantes. Até 1959, Markham considerava alguns vírus como "variantes" do tobamovírus do mosaico do tabaco (TMV), em particular o mosaico do tomateiro (ToMV) e, apesar de terem sido diferenciados mais tarde por Van Regenmortel (1982) e Bos (1983), sua distinção, quando ocorrem juntos infectando uma mesma planta, ainda é bastante difícil. Hoje, o ToMV é classificado como uma espécie pertencente ao gênero dos tobamovírus (Murphy et al., 1995).

A produção de anticorpos monoclonais aplicados a vírus de plantas e especificamente para o ToMV mostram-se pertinentes pela precisão e eficácia da metodologia, uma vez que soros policlonais anti-ToMV ou anti-TMV apresentam alta taxa de reação cruzada e a separação desses vírus pode ser feita somente através dos sintomas em planta teste de tabaco (Nicotiana tabacum var. White Burley e Nicotiana rustica), onde o ToMV apresenta lesões locais, pode-se utilizar também plantas de Petunia $x$ hybrida, que também apresenta lesão local ou Solanum giganteum, que apresenta mosaico sistêmico (Caner et al., 1990 e Jones et al., 1991).

Testes sorológicos tem sido aplicados a viroses por décadas e estão entre as mais importantes metodologias para a identificação e taxonomia de vírus (Halk \& De Boer (1985; Trione, 1988). Ensaios com adsorsão de anticorpos ligados a enzimas (ELISA "Enzyme-Linked Immunosorbent Assay") melhoraram consideravelmente a sensibilidade 
dos testes sorológicos convencionais (Clark \& Adams, 1977; Al Moudalall et al., 1984; Kitajima, 1991). O aumento da sensibilidade possibilitou identificar com precisão partículas virais em pequeno número, reduzindo-se significativamente as quantidades de reagentes e antissoros utilizados. Adicionalmente o teste ELISA tem grande valor em estudos epidemiológicos, com destaque para os vírus que infectam vegetais, e que ocorrem em baixas concentrações, e que manifestam poucos ou nenhum sintoma, a não ser a diminuição da produção (Voller et al., 1976).

A tecnologia de anticorpos monoclonais (MAbs) criada por Köhler e Milstein (1975) baseia-se na fusão de células de mieloma de camundongo, que se multiplicam sem diferenciar, com células provenientes do baço de camundongos secretoras de anticorpos. A célula híbrida (hibridoma) cresce indefinidamente em meio de cultura artificial secretando anticorpos altamente específicos contra o antígeno para o qual foram produzidos. Como cada célula produz um único anticorpo, clones destas células podem ser obtidos e expandidos, reconhecendo diferentes porções do antígeno. Tal metodologia deve tornar-se cada vez mais empregada para as viroses de plantas. Agronomicamente a quantificação da infestação pelo patógeno tem grande importância para a produção e distribuição de materiais livres de vírus em culturas propagadas por tubérculos, bulbos e indexação de doenças virais (Trione, 1988; Schots et al., 1996).

Existem diversos exemplos de aplicação de MAbs na agricultura, entre os quais Thomas \& Dietzgen (1991) que produziram e caracterizaram anticorpos monoclonais contra partículas semelhantes a vírus (fitoplasmas), causadoras da ramificação do ápice de bananeiras na Austrália ("bunchy top disease"). Até então, esta doença não tinha agente causal conhecido e através de isolamento do possível patógeno e ensaios do tipo ELISA 
com o uso de anticorpos monoclonais, Zhang et al. (1995) identificaram esta doença como causada pelo vírus BBTV. Os anticorpos monoclonais selecionados mostraram resultados positivos em diluições de 1:1280 de seiva de folhas de bananeiras doentes.

Culver \& Sherwood (1988) produziram "kits" com anticorpos monoclonais, para a detecção do vírus da estria da semente de amendoim (PStV- "peanut stripe virus") (Arachis hypogaea L.). O teste ELISA indireto foi utilizado para a titulação de anticorpos policlonais e monoclonais, bem como com a combinação deles. Os anticorpos monoclonais mostraram-se mais sensíveis, podendo detectar $2,5 \mathrm{ng} / \mathrm{ml}$ do vírus. Uma pequena porção do cotilédone de cada semente foi removido e testado para detectar a presença ou ausência do vírus. As sementes foram então semeadas e um novo teste ELISA foi feito para as plântulas, juntamente com uma planta testadora (Chenopodium amaranticolor). As sementes plantadas mostraram-se livres de vírus e o teste ELISA identificou a presença do patógeno em tecido cotiledonar. Todos os cinco cultivares de amendoim testados transmitem esta virose em taxas que variam de 0,4 a $5,0 \%$ do total de sementes comercializadas.

Anticorpos monoclonais para o vírus M da batata (PMV- "potato M-virus"), foram preparados por Järvekülg et al. (1989), sabendo-se que soros policlonais reconheciam até $40 \mathrm{ng} / \mathrm{ml}$ de PMV em tubérculos de batata, contudo sem diferenciar estirpes do PMV. O vírus foi purificado de folhas de tomateiro e estirpes fracas, moderadas e severas foram isoladas e caracterizadas. Os controles negativos foram feitos utilizando PVX, PVY, PVS e PLRV. Após a obtenção dos hibridomas, três clones foram selecionados e detalhadamente caracterizados em testes ELISA indireto em extratos de tubérculos infectados dos cultivares Ando, Adretta, Sulev Jógeva Kollane, Alōi, Mavka e 
Komsomolets, e também com tubérculos sadios. Os anticorpos reconheceram quantidades inferiores a $10 \mathrm{ng}$ de PVM por $\mathrm{ml}$, chegando a $1 \mathrm{ng} / \mathrm{ml}$. O "kit" produzido detecta tanto o PVX quanto o PVM em suco de tubérculos de batata (Solanum tuberosum).

Através de anticorpos monoclonais e policlonais Jones et al. (1989) fizeram a diferenciação de alguns vírus que infectam framboesa conhecidos como nepovírus do mosaico arábico (AMV- "arabis mosaic nepovirus") e vírus do mosaico em anel (RRV"raspberry ringspot neporivus"). Haviam dificuldades em diferenciar estirpes dos vírus em framboesas cultivadas na Inglaterra e Escócia, através de infecção natural, inoculação em plantas sadias e inoculação em planta-teste de Rubus. Através de testes sorológicos com soros policlonais e monoclonais, puderam ser feitas diferenciações entre isolados desses vírus em diferentes locais onde se cultivam diversas variedades de framboesa.

O primeiro trabalho de produção e utilização de anticorpos monoclonais detectando vírus contendo envelope e que infectam plantas, foi realizado por Sherwood et al. (1989), utilizando o complexo do vira cabeça do tomateiro (TSWV) purificado a partir de vários isolados de vírus de plantas de Datura stramonium L. infectadas. A atividade sorológica destes anticorpos foi determinada por PAS-ELISA (ELISA do tipo sanduíche com proteína A), ELISA indireto e "Dot-Immunobinding Assay"(DIBA).

Adam et al. (1995) também produziram anticorpos monoclonais contra os tospovírus do grupo dos TSWV, específicos para proteínas do tipo G (epitopos glicoprotéicos), provando que outros tospovírus possuem esta mesma glicoproteína. Estes anticorpos em ensaio TAS-ELISA ("triple antibody sandwich") mostraram reação com todas as estirpes do TSWV e com o INSV ("impatiens necrotic spot tospovirus"). 
Kawai et al. (1991) produziram anticorpos monoclonais contra o vírus do enrolamento das folhas de citrus (CTLV- "citrus tatter leaf virus"). Os hibridomas foram testados juntamente com soros policlonais obtidos e purificados de Chenopodium quinoa infectados com CTLV em ensaio de sanduíche duplo de ELISA indireto. Três clones foram escolhidos sendo isotipados como IgG1, que reagiram positivamente com 20 isolados do CTLV e com dois isolados do vírus do enrolamento do caule da macieira (SGCV- "stem grooving capillo virus"). Os três anticorpos monoclonais detectaram vírus através de sanduíche duplo de ELISA direto em seiva de Chenopodium quinoa diluída 1: 516 vezes e em seiva de plantas de citrus diluídas 1: 64 vezes.

Anticorpos monoclonais específicos para detecção de vírus do mosaico da macieira (ApMV- "apple mosaic ilarvirus") foram obtidos por Pasquini \& Barba (1991), através de fusão de mieloma com células secretoras de anticorpos produzidos em camundongo BALB/c imunizado com o isolado P86 deste vírus. Nove clones foram isotipados e caracterizados em teste ELISA. Todos os clones detectaram o ApMV em diferentes habitats naturais infectados, e não houve reação cruzada, quando os clones foram testados com plantas sadias ou com amostras de outras rosáceas (pêssego, nectarina, etc) infectadas com o PNRV ("prunus necrotic ringspot ilarvirus").

Di et al. (1993) produziram sete anticorpos monoclonais para a identificação de isolados do vírus do mosaico do caupi (CPSMV -"cowpea severe mosaic virus"), onde diferenças antigênicas foram identificadas nos isolados, em testes com seiva de plantas infectadas.

Para determinar a ocorrência de estirpes severas do vírus da tristeza do citrus (CTV), Lee et al. (1993), realizavam ensaios anuais com anticorpos monoclonais em DIBA 
e em sanduíche duplo de ELISA. Com o rastreamento das áreas onde ocorria a estirpe severa, os autores puderam também verificar o efeito de proteção que existia em plantas infectadas com estirpes fracas do CTV. Observações de Pappu et al. (1993) e Pappu et al. (1995) identificaram que existe um epitopo no capsídeo do CTV, que é altamente conservado nos anticorpos monoclonais comercialmente utilizados para a identificação deste closterovírus.

Hataya et al. (1994) utilizaram anticorpos monoclonais específicos para o vírus $\mathrm{Y}$ da batata (PVY), das estirpes $\mathrm{O}$ e $\mathrm{T}$. Em teste com amostras supostamente contaminadas com estes vírus, $22 \%$ apresentaram reação positiva com o anticorpo monoclonal PVY (O); 55\% das amostras apresentaram reação positiva com o anticorpo monoclonal PVY (T); 17 \% das amostras apresentaram reação positiva com ambos os anticorpos monoclonais e apenas $6 \%$ das amostras não apresentaram reação com nenhum dos dois anticorpos monoclonais.

Swanson \& Harrison (1994) produziram sete anticorpos monoclonais contra o "okra leaf curl virus" (OLCV), um vírus transmitido por mosca-branca, que infecta plantações de quiabo na África e Oriente Médio.

Jawee et al. (1995) produziram anticorpos policlonais e monoclonais contra o "strawberry mild yellow edge-associated potexvirus" (SMYEAV). Ambos os antissoros produzidos reagiram com especificidade contra o SMYEAV, em ELISA. As plantas de morango (Fragaria vesca) foram inoculadas com dois isolados deste vírus provenientes de plantações na Alemanha e 14 isolados da região sudeste da Inglaterra. Todos os isolados puderam ser identificados e caracterizados em folhas, flores e raízes dos morangueiros. 
Rampitsch et al. (1995) desenvolveram um sanduíche triplo de ELISA com MAbs para a detecção do nanismo do pessegueiro (PDV) em cerejeiras (Prunus avium) infectadas. A incidência do PDV foi verificada em 40 plantas, onde haviam sintomas da doença. Os anticorpos produzidos não apresentaram reação cruzada nos testes realizados com o NRSV, causador da mancha anelar necrótica do pêssego.

Coyone et al. (1997) desenvolveram um ELISA para testar resistência de amêndoas a diversas doenças, com o objetivo de se Ter um teste rápido para seleção de plantas resistentes, auxiliando no melhoramento genéticos desta espécie.

Na certificação de mudas de videira, Schieber et al. (199u7) produziram dez MAbs contra o vírus "fleck" e estes anticorpos foram capazes de identificar o vírus a partir de teste ELISA em 50 mudas originárias de diversas regiões da França. Não houve reações cruzadas com nenhum nepovírus ou closterovírus.

Com a finalidade de se fazer um teste capaz de detectar três vírus diferentes em plantas de tomate, anticorpos policlonais contra o ToMV, contra o víns do mosaico do pepino (CMV) e o Vírus Y da batata foram produzidos e utilizados para precipitação em látex e, posteriormente, acoplado em extrato de plantas de tomate infectadas e medido através de citofluorimetria, onde foi possível detectar os 3 vírus simultaneamente nas plantas de tomate (Iannelli et al., 1997).

Um grupo de 25 MAbs foram produzidos contra dois geminivírus (vírus do enrolamento da folha de tabaco (CLTV) e "vírus da estria amarela do croton" (CYVMV) transmitidos por mosca branca (Bemisia tabaci) e testados em Sanduíche triplo de ELISA (TAS-ELISA). Apenas um anticorpo monoclonal foi específico para diferenciar isolados indianos dos isolados do Paquistão, Uganda, Malawi e Burkina-Faso (Swanson et al., 
1998). Foram realizados também sanduíche duplo de ELISA (DAS-ELISA) mas o TASELISA se mostrou mais sensível.

$\mathrm{Na}$ caracterização de um novo potyvírus isolado do amendoim da África do Sul foram utilizados 17 anticorpos policlonais contra potyvírus diferentes em ELISA, além da microscopia eletrônica para comparação das estruturas. Cook et al. (1998) concluíram que trata-se de uma nova virose, pertencente ao gênero potyvírus.

Quatro MAbs produzidos contra o oírus Y da batata (PVY) foram testados contra quatro isolados de $\mathrm{PVY}^{\mathrm{NTN}}$ e um isolado $\mathrm{PVY}^{\mathrm{N}}$; contra o vírus do mosaico do nabo (TuMV), o vírus da quebra da tulipa (TBV), o vírus do mosaico severo da Íris (ISMV); vírus do mosaico da frésia (FMV) o mosaico amarelo do feijão (BYMV) e o "plum pox virus" (PPV). Um MAb mostrou-se específico para os isolados do tipo $\mathrm{PVY}^{\mathrm{NTN}}$ em ensaios de ELISA (Cerovská, 1998).

$\mathrm{O}$ vírus da mancha da ameixa (PPV) pode ser dividido em quatro grupos separados por diferenças sorológicas, epidemiológicas e moleculares. Anticorpos monoclonais foram produzidos por Candresse et al. (1998).para diferenciar dois grupos principais deste vírus: sorotipo $\mathrm{M}$ e $\mathrm{D}$, onde juntamente com PCR foi possível diferenciar isolados pertencentes a cąda um destes grupos.

Em estudos sobre a variabilidade de isolados do vírus da estria amarela do trevo (CIYVV) anticorpos monoclonais foram produzidos e testados em diferentes hospedeiros do vírus como Chenopodium amaranticolor, C. quinoa, Nicotiana clevelandii, N. benthamiana, Vicia fava e Trifolium repens, onde foi possível determinar dois sorotipos, baseados em sanduíche duplo de ELISA (Sasaya et al., 1997). 
Embora se fale muito em técnicas moleculares para diagnóstico de vírus de plantas como PCR, RT-PCR e RFLP, estas técnicas, ao contrario do ELISA não podem ser realizadas por agricultores, necessitam de um laboratório e de pessoal tecnificado para sua execução. Alguns trabalhos comparam as técnicas como o descrito por Schoen et al. (1996), que discutem a falta de praticidade nos testes do tipo RT-PCR, quando comparados com o ELISA para a detecção do vírus do enrolamento da folha de batata (PLRV), aplicados em tubérculos de batata em estado de dormência. Figueira et al. (1997) utilizaram DAS e TAS ELISA em comparação com o PCR na identificação do vírus do nanismo da cevada (BYDV) estirpe PAV-IL. Neste trabalho, o TAS-ELISA foi mais sensível que o DASELISA na detecção do vírus em extratos de plantas, mas quando comparados com o PCR, este método mostrou-se mais sensível, detectando quantidades bastante menores do vírus e utilizando quantidades menores de amostras. Por outro lado, quando se trata de um número grande de amostras, o ELISA mostrou-se um método muito mais fácil e econômico. Crescenzi et al. (1997) também utilizaram DAS-ELISA e RFLP para caracterização do PPV em cerejas doces (PPV-SwC), que é diferente do PPV. Utilizando anticorpos monoclonais, foi possível diferenciá-lo das outras estirpes PPV-SoC, PPV-D, PPV-M e PPV El em testes de DAS-ELISA que foram confirmados no RFLP. Reunindo as duas técnicas, Jacobi et al. (1998) desenvolveram um IC-RT-PCR (PCR de imunocaptura) para a detecção de ToMV e TMV em plântulas de pinus, utilizando anticorpos policlonais produzidos em coelhos.

Anticorpos monoclonais tem sido muito utilizados no estudo de movimento de partículas virais célula-a-célula, como no estudo deste movimento do "brome mosaic bromovirus" (BMV), que infecta cevada (Fujita et al., 1998). Neste trabalho, anticorpos 
monoclonais foram produzidos contra uma proteína do vírus, a B3a e foram capazes de detectar que o vírus forma complexos no citoplasma das células vegetais.

A utilização de "kits"de diagnóstico baseados em anticorpos monoclonais e policlonais tem movimentado milhões de dólares nos EUA a na Europa, onde grandes companhias se especializaram na produção e distribuição destes "kits", como a Agdia (http://www.agdia.com) que foi fundada em 1981, nos EUA e hoje produz e comercializa "kits" para mais de 150 patógenos e é a empresa de maior expressão no mercado mundial de "kits" de diagnóstico.

Baseado nestes dados e trabalhos acima relatados, a utilização de anticorpos monoclonais e policlonais aplicados à diagnose da fitopatógenos mostra-se bastante viável para a agricultura brasileira. 


\section{3 - MATERIAL E MÉTODOS}

\section{1 - Material Vegetal utilizado}

\section{Sementes:}

Foram utilizadas sementes de Tabaco da espécie Nicotiana rustica (tabaco asteca) e de Nicotiana tabacium "Turkish NN" foram cedidas pelo Prof. Dr. Jorge A. M. Rezende, do Depto. de Fitopatologia, Entomologia e Zoologia da ESALQ/USP.

\section{Plântulas:}

As plântulas de tomate variedade Santa Clara, com cerca de 40 dias de idade, utilizadas para reprodução dos sintomas do ToMV, foram cedidas pelo Produtor de mudas, Engenheiro Agrônomo Antonio Ledo, do Viveiro de mudas "Nova Era" (Fazenda Cantinho II - Município de Mogi-Guaçu -SP).

\section{2-Animais utilizados}

Camundongos singênicos da linhagem BALB/c mantidos no Biotério do Laboratório de Genética de Leveduras, ESALQ/USP foram utilizados para as imunizações 
e para o preparo de meios específicos. Os coelhos eram fêmeas da raça Nova Zelândia, com aproximadamente 2 meses de idade, foram cedidas pela Granja do Depto. de Produção Animal da ESALQ/USP.

\section{3- Origem e multiplicação dos tobamovírus}

Inóculo de ToMV, estirpe TM-1, armazenada em folhas de tomateiro foi cedido gentilmente pelo Prof. Dr. Marcelo A. Pavan, da UNESP, Botucatu-SP. O TMV, estirpe numerada 898/9718, armazenada em plantas de tabaco (Nicotiana tabacum "Turkish NN") foi cedida pelo Dr. Valdir Atsushi Yuki, Pesquisador Científico da Seção de Virologia Fitotécnica do IAC - Campinas-SP.

Para a multiplicação dos ToMV, sementes de tabaco da espécie Nicotiana rustica (tabaco asteca) foram semeadas em um vaso para a produção de mudas, que após cerca de 2 meses, as mudas foram transplantadas para vasos, em condição de casa de vegetação para o desenvolvimento de plantas adultas.

A multiplicação do TọMV foi feita na forma de inoculação mecânica, utilizando-se o folíolo de tomateiro infectado com ToMV estirpe TM-1 macerado em almofariz, na presença de PBS, na diluiç̧ăo de 1:20. Nas folhas adultas dos tomateiros foi polvilhado carborundo, e o inóculo foi aplicado por meio de fricção das folhạs com o indicador umedecido com o extrato. Após a inoculação, as folhas foram lavadas com água destilada para eliminar o excesso de carborundo. O TMV foi multiplicado em plantas de tabaco da espécie Nicotiana tabacum "Turkish NN", também através de inoculação mecânica. 
Ambos os tobamovírus foram purificados através de protocolo descrito em Matthews (1993), que consistiu em :

1 - homogeneizar o tecido infectado em 0,003 M de EDTA pH 7,0 (2ml/g de tecido) e 0,16 ml de 2-mercaptoetanol por $100 \mathrm{ml} \mathrm{de} \mathrm{tampão;}$

2 - filtrar o extrato em gaze e aquecer a $55^{0} \mathrm{C}$ por $10 \mathrm{~min}$;

3 - centrifugar $20 \mathrm{~min}$. a $3.000 \mathrm{~g}$;

4 - coletar o sobrenadante e centrifugar por 2 horas a $29.500 \mathrm{~g}$;

5 - ressuspender o precipitado em 0,003 M EDTA, pH 7,0 (1ml/tubo), durante a noite, a 4 ${ }^{0} \mathrm{C}$;

6 - centrifugar a suspensão durante $25 \mathrm{~min}$. a $10.000 \mathrm{~g}$;

7 - preparar um gradiente de sacarose no dia anterior (10-40\%); colocar a suspensão de vírus sobre o gradiente de sacarose e centrifugar por $2: 45 \mathrm{~h}$ a $24.500 \mathrm{~g}$, a $14^{\circ} \mathrm{C}$;

8 - coletar a zona contendo o vírus e diluir com tampão EDTA;

9 - centrifugar por $2 \mathrm{~h}$. a $29.500 \mathrm{~g}$;

10 - ressuspender o precipitado durante a noite em EDTA ( $1 \mathrm{ml})$.

\section{4 - Obtenção dos anticorpos monoclonais e policlonais}

A produção de anticorpos monoclonais seguiu os passos descritos em seguida, conforme exemplificado na figura 1. 


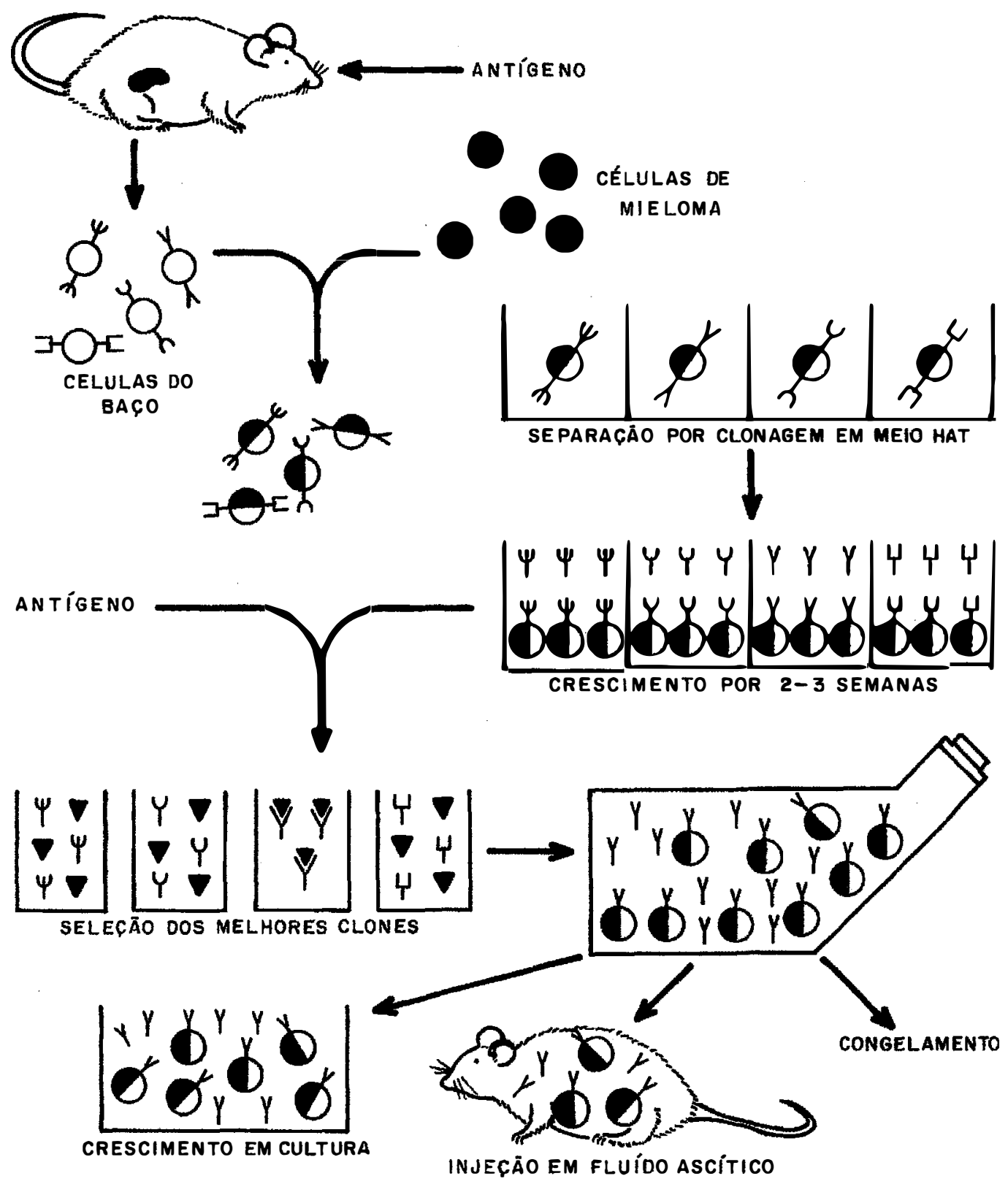

Figura 1 - Esquema de produção de anticorpos monoclonais segundo Campbell (1984) adaptado por Duarte (1996). 


\subsection{1 - Imunização dos Animais}

Quatro camundongos fềmeas BALB/c, de dois meses de idade receberam aproximadamente $20 \mu \mathrm{g}$ do antígeno puro em cada injeção de imunização. A primeira imunização foi feita na forma de injeções subcutâneas de $0,1 \mathrm{ml}$ em quatro sítios diferentes, próximos às cadeias ganglionares dos membros anteriores e posteriores (Hurn \& Chantler, 1980) com Adjuvante Completo de Freund (F5881 - Sigma) e PBS na proporção de 1:3 (v/v). A segunda imunização, realizada de 20 dias após, foi utilizado Adjuvante-Ingẹmpleto de Freund (F5506 - Sigma) e PBS (Phosphate Buffer Solution - solução tampão de fosfato) para incorporação do imunógeno, também por via subcutânea, na proporção de 1:3 (v/v).

As imunizações seguintes a intervalos também de 20 dias, foram feitas diluindo-se o antígeno em PBS, de forma a ter um volume final de $200 \mu$ por camundongo, e injetado via intraperitoneal.

Uma fêmea de coelho foi imunizada com uma suspensão de 40 ug de antígeno em cada injeção, utilizando o mesmo protocolo utilizado para os camundongos. $\mathrm{O}$ sangue foi coletado antes de cada nova imunização através de corte na orelha do animal, seguido de repouso por 1 hora a $37^{\circ} \mathrm{C}$ e centrifugação para separação do soro.

Antes de cada nova imunização, alíquotas de sangue foram coletadas do plexo ocular dos camundongos e deixadas a $37{ }^{\circ} \mathrm{C}$ por 1 hora para coagulação e centrifugadas para a separação do sọro, a $200 \mathrm{X}$ g por 2 minutos.

A titulação dos soros dos animais foi realizada por teste indireto de ELISA, do tipo "Plate Trapped Antigen" (PTA-ELISA) (Crowther, 1995) para determinação da 
melhor concentração do antígeno necessário na sensibilização das placas e da concentração dos soros, otimizando o ELISA.

Selecionou-se assim o camundongo que melhor respondeu ao esquema de imunizações, apresentando maior título em ELISA, para a realização da fusão, recebendo uma injeção intravenosa de 15 a 25 ug do antígeno em PBS, dois dias antes da fusão.

\subsection{2 - Ensaio imunoenzimático}

A titulação dos soros de camundongo (ou de coelho), bem como a análise dos sobrenadantes de cultura dos híbridos murinos obtidos, foram feitas numa primeira etapa, através de ensaio imunoenzimático do tipo PTA-ELISA (Mowat \& Dawson, 1987; Crowther 1995). Resumidamente, as placas de polivinil de 96 orifícios foram sensibilizadas com antígeno, colocando-se $50 \mu$ por poço, sendo incubadas por 1 hora a $37^{\circ} \mathrm{C}$.

Após a sensibilização, os sítios ativos remanescentes do plástico foram bloqueados com $200 \mu \mathrm{l}$ de tampão de bloqueio (TB1) por poço, por mais uma hora a $37^{0} \mathrm{C}$, batendo-se a placa após este período para descarte do líquido em excesso. Em seguida, sobrenadantes de cultura ou diluições dos soros de camundonge a serem testados foram adicionados às placas, nas diluições preestabelecidas, em duplicatas, e incubados por uma hora a $37^{\circ} \mathrm{C}$.

Os orifícios foram então lavados com $200 \mathrm{ml}$ de PBS-T-G por 3 vezes. A placa foi seca batendo-se em papel absorvente até que o excesso de líquido fosse eliminado. A seguir, fez-se a incubação uma hora a $37^{\circ} \mathrm{C}$, com conjugado anti-imunoglobulina IgG de camundongo marcado com peroxidase (leitura a $492 \mathrm{~nm}$ ) ou fosfatase alcalina (leitura a 
$405 \mathrm{~nm}$ ) ("blotting grade affinity purified goat anti-mouse IgG $(\mathrm{H}+\mathrm{L})$ human $\operatorname{IgG}$ conjugate" - Bio Rad).

Após mais 3 lavagens com PBS-T-G, como descrito anteriormente, a reação foi revelada, utilizando tanto a peroxidase como a fosfatase alcalina como enzima. No caso de marcação com peroxidase, o substrato utilizado para reação foi orto-fenilenodiamina (OPD) contendo $\mathrm{H}_{2} \mathrm{O}_{2}$, diluído em tampão de OPD, no escuro por 2 a 3 minutos e bloqueada com solução de $\mathrm{H}_{2} \mathrm{~S} 2,5 \mathrm{M}$, procedendo-se a leitura em leitor de placa de ELISA, a $492 \mathrm{~nm}$. No caso da marcação ser com fosfatase alcalina, a revelação foi feita com pNitrofenil fosfato (PNPP) dissolvido em tampão de PNPP, na proporção de $2 \mathrm{mg} / \mathrm{ml}$ e lido a $405 \mathrm{~nm}$.

As leituras foram realizadas em leitor de microplacas (Bio Rad mod. 550) e foram consideradas reações positivas as amostras com 3 repetições e que apresentaram média superior a 3 vezes o controle negativo (Sutula et al., 1986).

\subsection{3 - Obtenção de "Feeder Layer" de macrófagos}

O "feeder layer" de macrófagos (FDM) foi preparado com antecedência de 48 horas, sendo utilizados camundongos singênicos da linhagem BALB/c. Cada camundongo foi sacrificado em éter etílico e lavado em seguida em água corrente, sendo mergulhado em solução de álcool a $70 \%$ por 2 a 3 minutos. Em seguida foi separada a pele do camundongo, deixando exposta a cavidade peritoneal, tendo o cuidado de não rompê-la. Com uma pinça de ponta lisa, a membrana que recobre a cavidade peritoneal foi levantada e com uma tesoura foi feito um pequeno corte. Através desta abertura, com uma pipeta plástica esterilizada contendo cerca de 2 a $3 \mathrm{ml}$ de meio RPMI-1640, foi lavada a cavidade 
intraperitoneal, sendo recolhida a suspensão logo em seguida, num tubo cônico esterilizado de $50 \mathrm{ml}$. As células raspadas da cavidade (figura 2) foram então contadas em câmara de Neubauer e o tubo centrifugado por 6 minutos a $200 \mathrm{~g}$.

O sobrenadante foi descartado e o precipitado foi ressuspendido a partir da contagem de modo a serem distribuídas de $2-4 \times 10^{3}$ macrófagos/ orifício em placas de 96 poços, $10^{4}$ macrófagos/ orifício em placas de 24 poços e, nas garrafas de $25 \mathrm{~cm}^{2}, 1-2 \mathrm{x}$ $10^{5}$ macrófagos/garrafa. Os macrófagos foram mantidos a $37^{\circ} \mathrm{C}$ em estufa mantenedora de atmosfera de $95 \%$ de umidade e $5 \%$ de $\mathrm{CO}_{2}$.

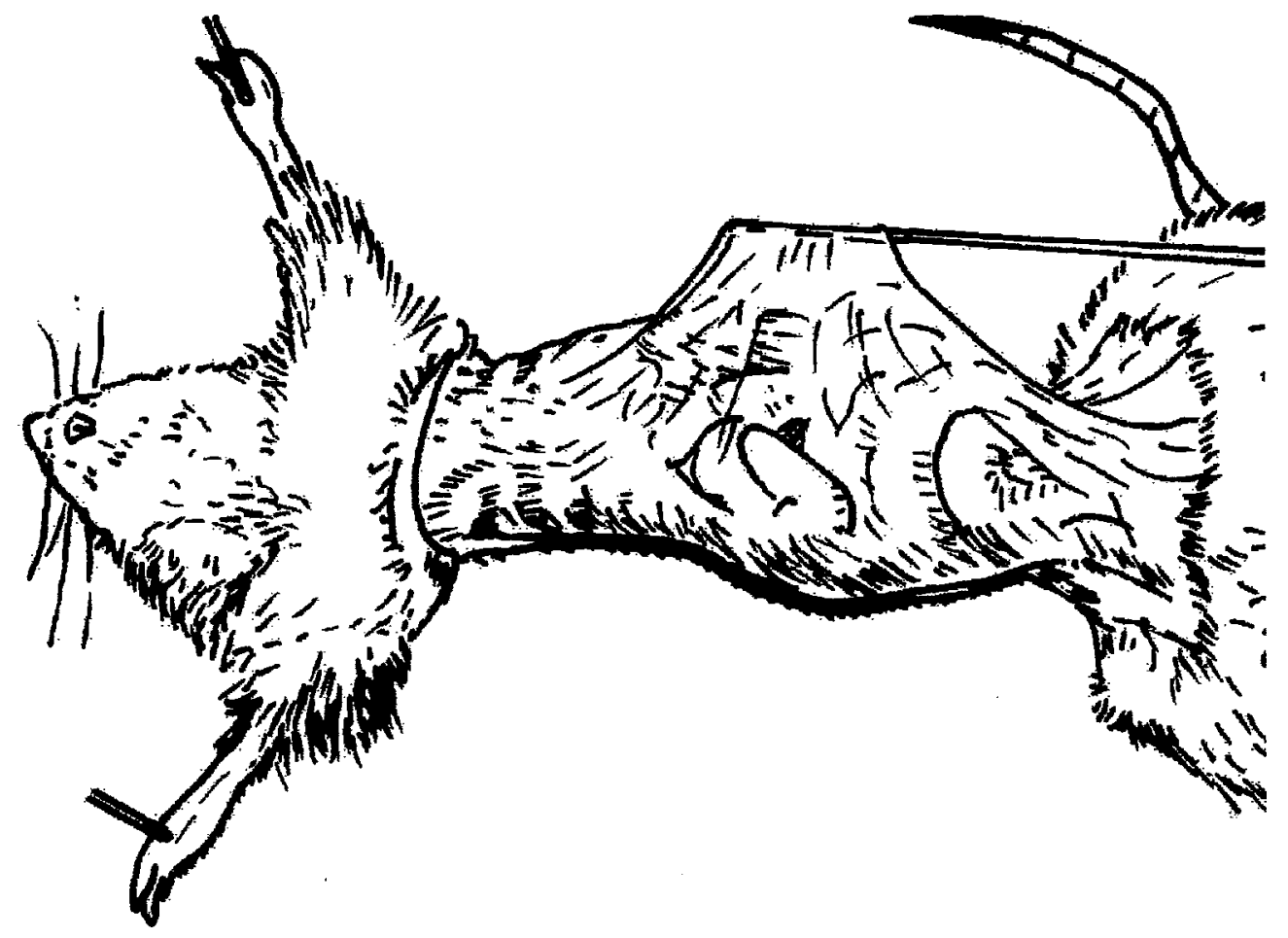

Figura 2 - Esquema da cavidade peritoneal de um camundongo de onde são retirados os macrófagos (Duarte, 1996). 


\subsection{4 - Fusão celular}

O camundongo teve seu baço retirado asceticamente sob fluxo laminar vertical e transferido para placa de Petri contendo $5 \mathrm{ml}$ de meio RPMI-1640 (GIBCO BRL cat. 31800-022). Com o auxílio de pinças, esmigalhou-se o órgão para a liberação das células. A suspensão celular foi então filtrada em tela de nylon para retirada dos fragmentos grosseiros e as células transferidas para tubo cônico de $50 \mathrm{ml}$, que já continha de $2 \mathrm{a} 5 \times 10^{6}$ células da linhagem SP2/0Ag14 (SP2) de mieloma de camundongo, fornecidas pela UNIFESP, não secretoras de imunoglobulinas, resistentes à 8-aza-guanina foram utilizadas para a realização da fusão, obtidas de culturas semi-confluentes (Kearney et al.,1979; Shulman et al.,1985). As culturas foram mantidas em meio RPMI 1640, contendo $10 \%$ de soro fetal bovino (R10), em atmosfera úmida de $5 \%$ de $\mathrm{CO}_{2}$.

Adicionou-se à mistura de células, gota a gota, sob agitação leve e durante 30 segundos, $1 \mathrm{ml}$ do agente fusionante preparado previamente, contendo polietilenoglicol (PEG de PM 3000-3700, ATCC, Rockville, MD 20852, USA), mantendo agitação suave por um minuto. Adicionando-se, sob agitação suave, $1 \mathrm{ml}$ do meio em 30 segundos; $3 \mathrm{ml}$ do meio em 30 segundos; $16 \mathrm{ml}$ do meio por 60 segundos e finalmente, completando o volume para $50 \mathrm{ml}$. Após repouso de 5 minutos, seguiu-se centrifugação de 200 g por 10 minutos. O sedimento foi ressuspendido em $30 \mathrm{ml}$ de meio R10 seguido de nova centrifugação.

Novamente o sedimento foi ressuspendido em meio HAT, em volume adequado para a distribuição nas placas de cultura de 96 poços (2 gotas por poço, equivalente a $100 \mathrm{ml}$ de líquido), contendo "feeder layer" de macrófagos (FLM) também cultivadas em meio HAT (St. Groth \& Scheidegger, 1980 e Lopes et al., 1992) 


\subsection{5 - Congelamento e descongelamento de células}

O congelamento de hibridomas foi feito em alíquotas de $1 \mathrm{ml}$ contendo 0,5 $\mathrm{ml}$ de meio de congelamento mais $0,5 \mathrm{ml}$ da suspensão de células contendo $4 \times 10^{6}$ células, obtendo uma concentração final de $2 \times 10^{6}$ células por ml, estocadas por 24 horas à $-70^{\circ} \mathrm{C}$.

O descongelamento de células de mieloma foi efetuado em banho-maria a 37 ${ }^{0} \mathrm{C}$, transferindo-se imediatamente para tubos de centrífuga e diluindo-se gota a gota em 9 $\mathrm{ml}$ de meio R10. As células foram mantidas em repouso por 5 minutos e centrifugadas à $200 \mathrm{~g}$ por 6 minutos. Após o descarte do sobrenadante, as células foram novamente ressuspendidas em $1 \mathrm{ml}$ de meio $\mathrm{R} 10$ e transferidas para garrafas de cultura de $25 \mathrm{~cm}^{2}$ contendo 4 a $5 \mathrm{ml}$ de meio R10 fresco.

As células foram então cultivadas em meio R10, a $37{ }^{\circ} \mathrm{C}$, em estufa automática mantenedora de atmosfera de $95 \%$ de umidade e $5 \%$ de $\mathrm{CO}_{2}$.

Para a expansão de linhagens celulares aderentes, culturas confluentes foram descoladas batendo-se levemente com a palma da mão ao fundo da garrafa. No caso dos hibridomas e das células de mieloma para a fusão, a remoção foi feita através de raspagem das culturas com "cell scrapers" (NUNC 179693).

\subsection{6 - Clonagem e Reclonagem dos melhores híbridos}

Transcorridos cerca de 10 dias da fusão, nos orifícios das placas onde pôdese observar crescimento de colônias de hibridomas, tais colônias, denominadas "mães" 
foram submetidas a um rastreamento para seleção das melhores colônias secretoras de anticorpos através de um ELISA indireto, da mesma forma descrita acima, utilizando como soro $50 \mu 1$ do sobrenadante dos orificios que apresentam crescimento.

Para a realização da clonagem, cada colônia "mãe" foi submetida separadamente a uma contagem de células e ressuspendida em meio R10 a fim de se obter 100 a 150 células em $6 \mathrm{ml}$ (volume necessário para se colocar uma gota em cada orifício da placa de cultura de 96 orifícios), deste modo, cada gota contém aproximadamente uma célula, que ao crescer será um só clone. Desta forma, teremos novamente placas de 96 orificios, que após 10 dias foram submetidas a um novo rastreamento e seleção, pelo teste indireto de ELISA.

Após a seleção dos clones, as células foram transferidas para placa de 24 orificios contendo meio HT ou R20, com FLM e posteriormente expandidas para garrafas de $25 \mathrm{~cm}^{2}$ e depois para garrafas de $75 \mathrm{~cm}^{2}$. No caso de se desejar um crescimento mais tápido (há células que demoram muito a crescer em meio artificial) e para purificar as células, quando havia suspeita de contaminação, as células de cada cultura foram centrifugadas, ressuspendidas em meio RPMI e injetadas em camundongos previamente injetados com 0,5 ml de óleo mineral Pristane (2,6,10,14-tetramethylpentadecane, Sigma, cat. P 1403) 48 horas antes de receber as células, para produção de ascite (Johnstone \& Thorpe, 1982).

Transcorridos 7 a 15 dias, o líquido ascítico foi retirado asceticamente, centrifugado e o "pellet" ressuspendido em meio R10 e colocado em garrafas de $25 \mathrm{~cm}^{2}$ para crescimento em estufa incubadora de $\mathrm{CO}_{2}$, a $37^{\circ} \mathrm{C}$. 
A colônia obtida anteriormente produzidas contra o ToMV (10H1), que encontrava-se armazenada a $-70{ }^{\circ} \mathrm{C}$, foi descongelada e passada para garrafas de cultura de $25 \mathrm{~cm}^{2}$ contendo "Feeder Layer" de macrófagos e meio R10 para recuperação em meio artificial (Duarte, 1995).

Após cerca de 10 dias, foram submetidas a clonagem, cada uma sendo distribuída em 10 placas de cultura de 96 orifícios contendo "Feeder Layer" de macrófagos e meio R10.

\section{5- Coleta de material em campo}

Foram realizadas coletas de material contaminado com ToMV na região próximo ao centro de aparecimento da doença (a doença foi primeiramente relatada no país no município de Conchal (Caner et al., 1990)). Estas amostras foram coletadas no município de Mogi-Guaçu e Aguaí, onde encontram-se diversos produtores de tomate e o maior viveiro de mudas de tomate da região, conforme mapa na figura 3.

Amostra 1

Fazenda Cantinho I - Município de Mogi-Guaçu

Proprietário: Aparecida Munhoz Amâncio

Variedade Plantada: Santa Clara

Áręa Plantada: 50.000 pés de tomate

Época de coleta: colheita de frutos

Viroses constatadas: ToMV em folhas e frutos e complexo Vira-cabeça 
Amostra 2

Fazenda Cachoeira - Município de Aguaí

Proprietário: Antonio Demétrio

Variedade Plantada: Santa Clara

Área Plantada: 30.000 pés de tomate

Época de coleta: colheita de frutos

Viroses constatadas: ToMV em folhas, mosaico dourado e complexo Vira-cabeça

\section{Amostra 3}

Viveiro de mudas "Nova Era" - Fazenda Cantinho II - Município de Mogi-Guaçu

Proprietário: Engenheiro Agrônomo Antonio Ledo

Variedades Plantadas: Santa Clara (tomate salada comum), Débora (tomate salada tipo Longa-Vida) e Carmem (tomate caqui tipo Longa-Vida)

Época de coleta: mudas sadias com 40 dias, prontas para replante no campo.

Das amostras infectadas foram coletadas as folhas com sintomas das quais foi feita uma suspensão e reinoculadas em plantas de tabaco (Nicotiana rustica), e em plantas de tomateiro var. Santa Clara, que apresentaram sintomas característicos após 15 dias de inoculação. As plantas de tabaco foram cultivadas e inoculadas segundo protocolo já descrito anteriormente e as plantas de tomateiro foram obtidas do produtor de mudas $\mathrm{Sr}$. Antonio Ledo. 
Outra parte da suspensão das folhas infectadas foi utilizada para realização de testes do tipo ELISA. As plantas sadias serviram como controle negativo nos testes e para multiplicação do ToMV.

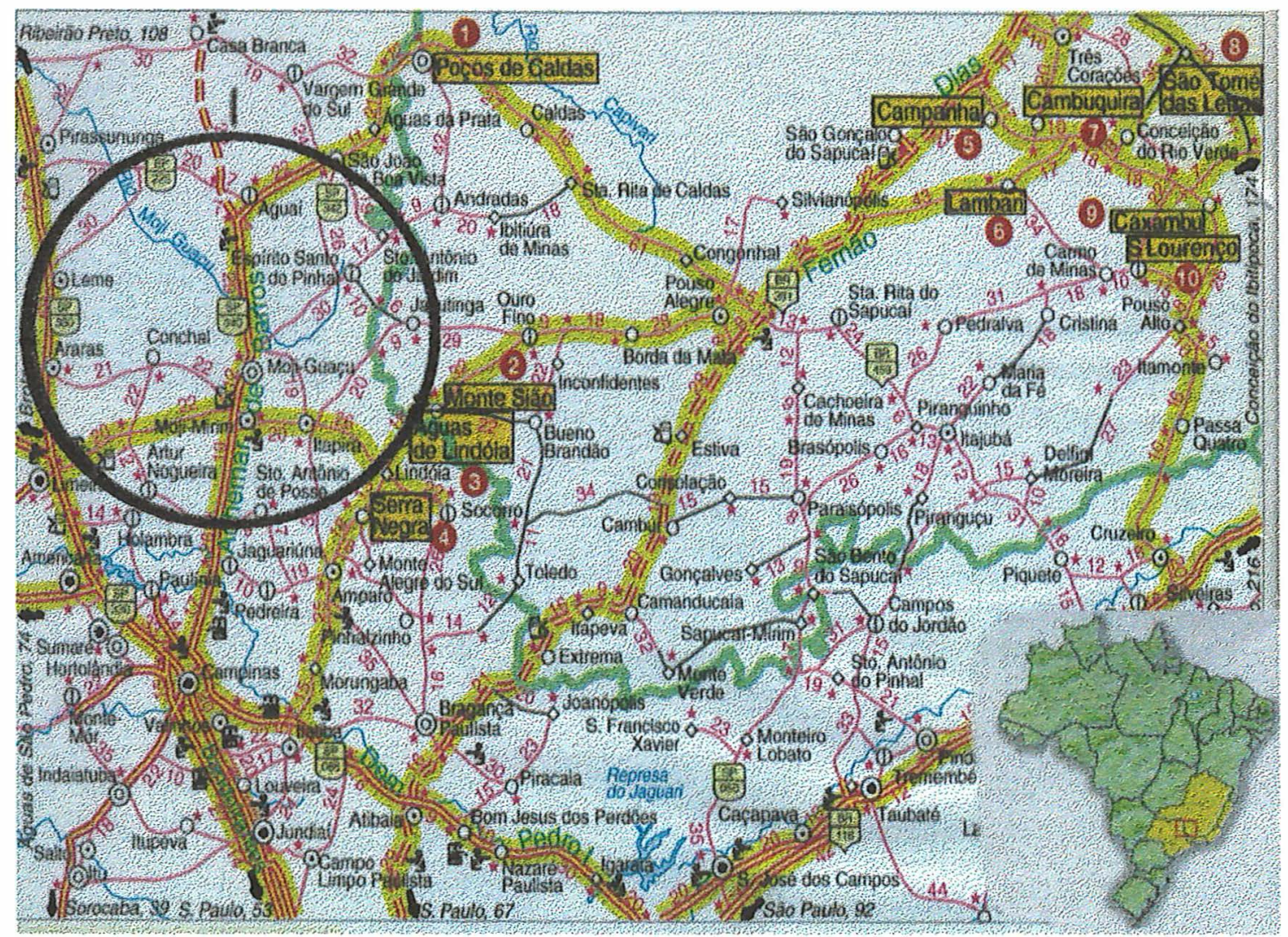

Figura 3 - Mapas mostrando a região do Brasil referente aos municípios mencionados e, no plano mais detalhado circundado em preto, as cidades de Conchal, local de aparecimento do ToMV no país; Aguaí e Mogi-Guaçu, regiões produtoras de tomate.

Nas figuras abaixo (Figura 4, 5 e 6) estão ilustrados o aspecto das plantas sadias e infectadas coletadas. 
Foliolos e frutos com sintomas de ToMV (Amostra 1 )
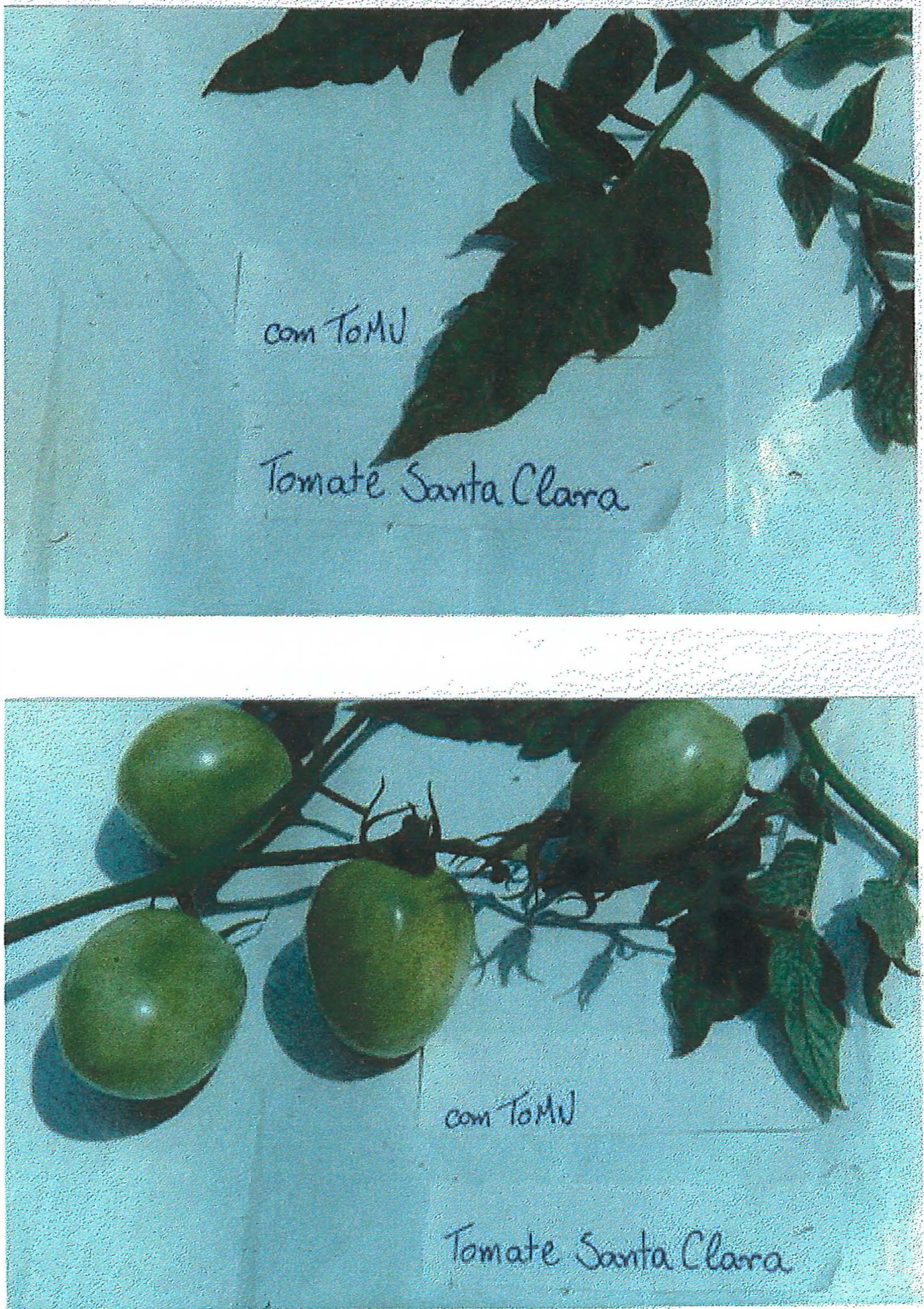

Figura 4 - Planta e frutos de tomate var. Santa Clara exibindo sintomas de ToMV, como manchas nos folíolos e nos frutos. 
Folla de tomate com ToNV e com o Complexo do Vira-cabeca
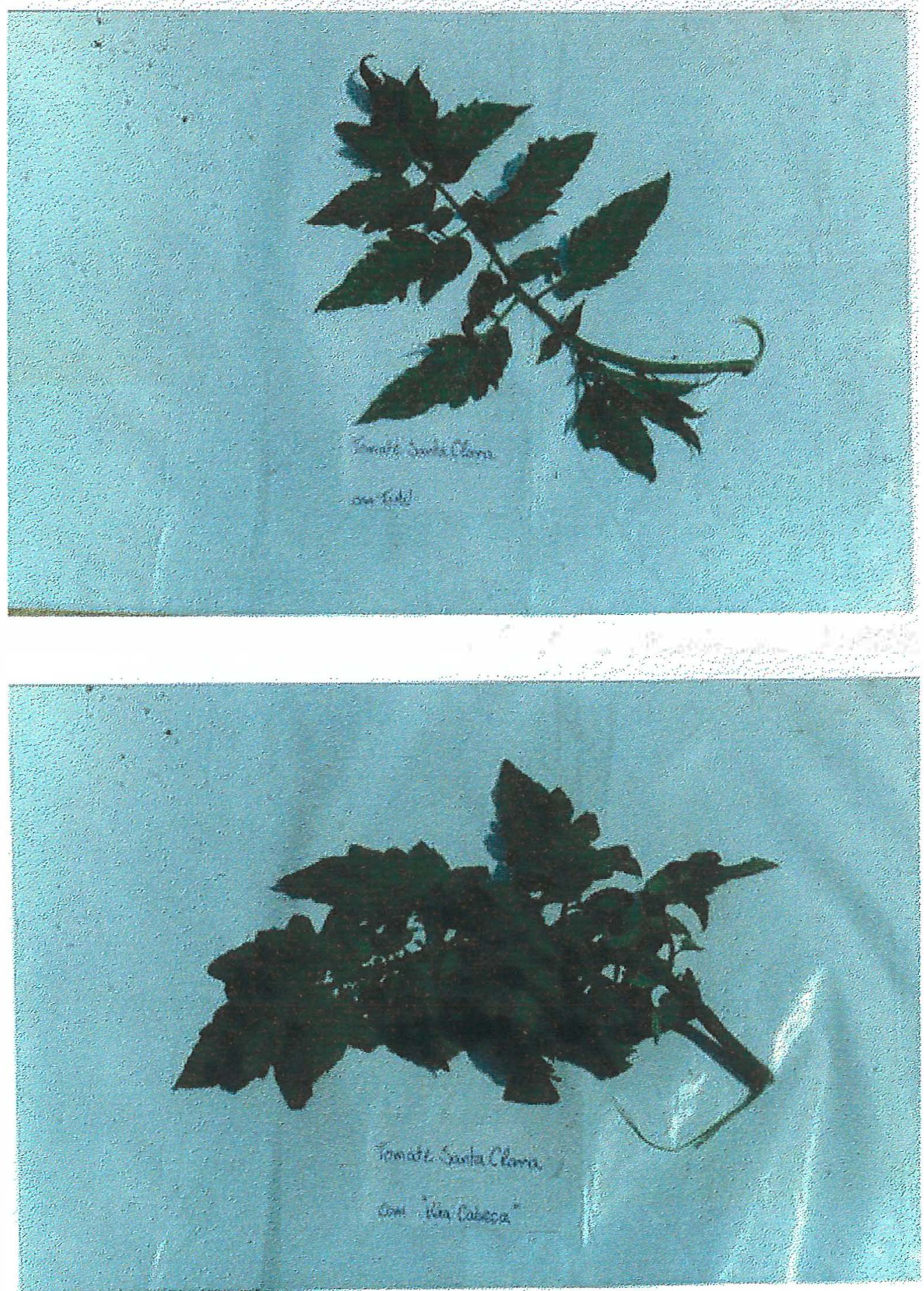

Figura 5 - Plantas de tomate var. Santa Clara com sintomas do ToMV (acima) e do complexo do "vira-cabeça" (abaixo). 


\section{Planta no campo com sintoma de ToMV ( Amostra 2)}

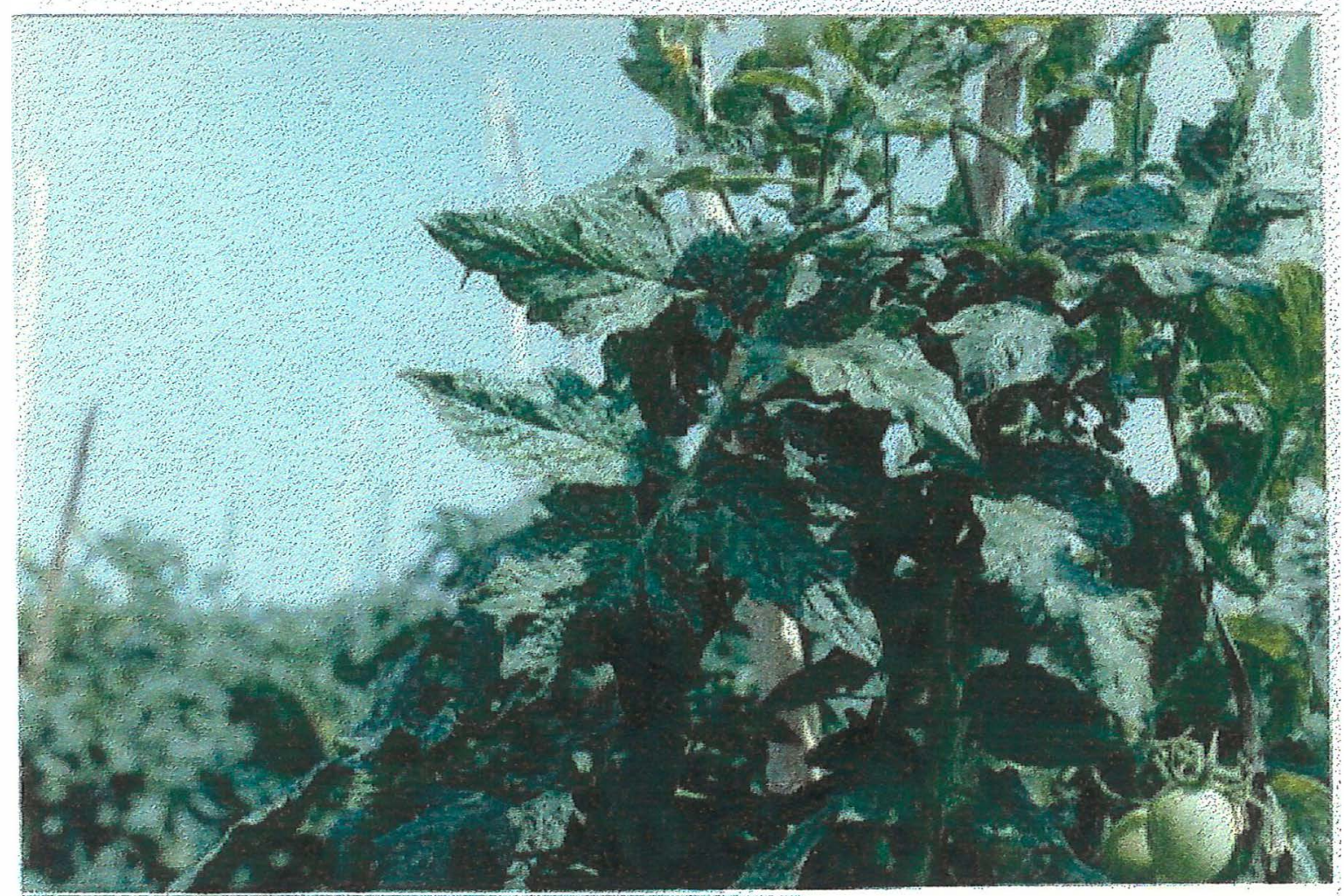

Figura 6 - Planta de tomate, var. Santa Clara, no campo exibindo início dos sintomas de infecção por ToMV (mosaico e enrugamento dos folíolos).

Nas figuras 4, 5 e 6 vemos folhas frutos e plantas de tomate var. Santa Clara com sintomas de ToMV e do complexo do Vira-cabeça, virose mais comum nas regiões onde foram efetuadas as coletas. 


\section{6- Caracterização dos anticorpos monoclonais e policlonais}

\subsection{1 - Isotipagem}

Para a isotipagem dos anticorpos monoclonais foi utilizado um "kit Immuno Select" (monoclonal antibody-based isotyping system for mouse immunoglobulins - Gibco BRL - cat. no. 9660SA), seguindo as especificações do fabricante, contendo os seguintes padrões de imunoglobulinas:IgG1, IgG2a, IgG2b, IgM, IgA, Kappa e Lambda.

\subsection{2 - Purificação em Coluna de Proteína A ( Oi \& Herzenberg, 1980)}

1- Preparar a coluna de sefarose-proteína A conforme instruções do fabricante;

2 -Lavar a coluna com tampão PBS acrescido de timerosal $1 \%$ por 1 hora;

3 - Preparo do anticorpo - para cada 1,5 ml de soro, adicionar $4 \mathrm{ml}$ de tampão Tris- $\mathrm{NaCl}$ (Tris $50 \mathrm{mM}$ e $\mathrm{NaCl} 0,15 \mathrm{M}, \mathrm{pH}$ 6,8) e filtrar em membrana esterilizada de 0,22 um;

4 - Passar o anticorpo na coluna em sistema fechado por 2 horas;

5 - Lavar a coluna com Tampão Tris $\mathrm{NaCl}$ por 1 hora;

6 - Passar tampão Glicina- $\mathrm{NaCl}$ (Glicina 50mM, $\mathrm{NaCl} 0,15 \mathrm{M}, \mathrm{pH} 3,0$ ) pela coluna e recolher 10 frações de $2 \mathrm{ml}$ em tubos contendo 50 ul de tampão Tris- $\mathrm{HCl}$ (Tris $1 \mathrm{M}, \mathrm{pH}$ 9,0). Fazer um tubo com tampão Glicina- $\mathrm{NaCl}$ e 50 ul de tampão Tris-HCl para ser utilizado como branco da quantificação;

7 - Lavar o sistema por 1 hora com PBS-timerosal $1 \%$; 
8 - Ler as amostras coletadas utilizando o teste de Bradford, em placa de ELISA, contendo 20 ul da amostra e 200 ul do reagente de Bradford;

9 - Os orificios da placa que se mostrarem azuis, faz-se a leitura da amostra em espectrofotômetro a $280 \mathrm{~nm}$

10 - Calcular a quantidade de IgG (para cada 1,3 D.O. $280 \mathrm{~nm}=1 \mathrm{mg}$ de $\mathrm{IgG}$ ).

\subsection{3 -Ensaio de Competição}

Este ensaio foi realizado para medir a especificidade do clone $10 . \mathrm{H} 1 \mathrm{e}$ constitui-se num teste de ELISA, onde a placa foi sensibilizada com o soro de coelho, que depois recebe o antígeno e os demais passos do protocolo previamente estabelecido, utilizando o MAb 10.H1 produzido via ascite e quantificado (Schechter \& Lopes, 1990).

\subsection{4 - Ensaio de Reatividade do ToMV e Utilização do Tampão de}

\section{Bloqueio ao longo do tempo}

Estes dois ensaios foram realizados visando a utilização deste teste na agricultura, e teve dois objetivos: primeiro, verificar a importância do uso do Tampão de Bloqueio (PBS acrescido de $1 \%$ de BSA), que além da Albumina Bovina ser onerosa, constitui num passo a mais do teste; segundo, verificar a reatividade do ToMV no teste, caso a placa fosse deixada à temperatura ambiente pelo período de até 30 dias. 
O ensaio foi conduzido sensibilizando-se 28 placas no mesmo dia e, 14 placas receberam o tampão de bloqueio e as 14 restantes não. A cada dia, as placas deixadas a temperatura ambiente, foram utilizadas para continuidade do teste de ELISA. Foi usado o Ascite do clone 10.H1, que foi acondicionado em geladeira durante os 30 dias do teste (uma vez que normalmente o ascite fica armazenado em Freezer a $-20{ }^{0} \mathrm{C}$ ).

\subsection{5 - Ensaio com plantas infectadas}

Foram utilizadas plantas de tabaco $N$. rustica infectadas com ToMV, com TMV e plantas sadias para realização deste ensaio. O extrato das folhas foi obtido macerando-se $1,0 \mathrm{~g}$ de folha congelada em nitrogênio líquido em $10 \mathrm{ml}$ de PBS. A solução foi centrifugada, e o sobrenadante guardado a $-20{ }^{0} \mathrm{C}$. Foram utilizados extratos em três diferentes diluições a partir da solução estocada.

\subsection{6 - Teste com as amostras coletadas}

Para o ELISA, foram maceradas amostras das plantas e frutos infectados e das plantas sadias, na concentração de $0,1 \mathrm{~g} / \mathrm{ml}$ de tampão PBS, usando também a planta com o complexo do vira-cabeça como controle negativo. 


\subsection{7 - Teste biológico com plantas de tomate e de tabaco}

Plantas de tomate var. Santa Clara foram cultivadas e o ToMV isolado foi re-inoculado nestas plantas para confirmação dos sintomas.

\subsection{8 - Eletroforese de proteínas totais (SDS-PAGE)}

Os géis de proteína total SDS-PAGE foram realizados segundo Laemmli (1970), utilizando gel de $10 \%$ e de $3 \%$ em sistema vertical da Hoefer $16 \mathrm{~cm}$.

As amostras foram adicionadas nas canaletas e cobertas com tampão de corrida, o qual também foi adicionado nas partes superior e inferior da cuba. Uma canaleta ficou sempre reservada para a adição de $5 \mu l$ do padrão de peso molecular (PharmaciaLMW - COD. 17-0446-01) e a corrida foi conduzida a 80 volts e $40 \mathrm{~mA}$ no gel empilhador e 120 volts e $60 \mathrm{~mA}$ no gel separador. Proporções previamente definidas para dois géis de $1 \mathrm{~mm}$. Os géis foram corados com prata segundo protocolo descrito em Gomes (1995).

Para a coloração de prata, após a corrida, o gel foi transferido para uma bandeja plástica com tampa contendo $250 \mathrm{ml}$ de solução fixadora e deixado a temperatura ambiente durante a noite (aproximadamente 15 horas). A solução fixadora foi substituída por $250 \mathrm{ml}$ da solução incubadora.

Após 15 minutos a solução incubadora foi retirada lavando-se o gel três vezes em água deionizada. Cada lavagem foi feita por 10 minutos e sob agitação constante. Adiciona-se ao gel a solução de prata por 20 minutos, após o que, esta é substituída Por 
$250 \mathrm{ml}$ de solução reveladora até o aparecimento das bandas. A solução reveladora foi descartada e adicionado a solução "stop" por 10 minutos, seguindo-se a lavagem do gel em água corrente por 2 horas. A água utilizada para esta lavagem não necessita ser deionizada nem destilada.O gel foi conservado em solução de glicerol $10 \%$ em água.

\subsection{9 - Imuno Blot (Harlow \& Lane, 1988)}

Foi utilizado o sistema de transferência "Mini-V8.10 Vertical Gel Electrophoresis System" (Gibco BRL cat. 21078), seguindo o procedimento descrito Protocolo 1 para anticorpos policlonais e Protocolo 2 para o anticorpo monoclonal.

\subsubsection{1 - Protocolo 1}

1 - Após a corrida do gel de SDS-PAGE, colocar o gel no sistema para transferência em membrana de nitrocelulose, utilizando o Tampão de transferência (24.8 mM tris; 192 mM glicina; $10 \%$ metanol; ajustar o $\mathrm{pH}$ para 8,3 e manter a $4{ }^{\circ} \mathrm{C}$ ), por $1: 30 \mathrm{~h}$;

2 - A membrana deve ser então corada em solução de vermelho de Ponceau $(0,5 \%$ Ponceau-S, $1 \%$ ácido acético, $100 \mathrm{ml}$ de água deionizada) por $10 \mathrm{~min}$ e após a confirmação da transferência, lavada em PBS;

3 - Bloquear por $2 \mathrm{~h}$ em tampão de bloqueio (3\% BSA; 0,02\% azida sódica), sob agitação;

4 - Lavar 5 vezes em solução de PBS e 0,1 \% tween 20, 5 min. Cada lavagem; 
5 - Incubar com o anticorpo policlonal de coelho na concentração de $50 \mathrm{ug} / \mathrm{ml}$ adicionado de $1 \%$ de NP40 por $1 \mathrm{~h}$;

6 - Lavar com PBS;

7 - Incubar com conjugado anti-coelho marcado com fosfatase alcalina por $1 \mathrm{~h}$;

8 - Revelar com 44 ul de NBT dissolvido em $10 \mathrm{ml}$ de tampão PA ( $10 \mathrm{mM} \mathrm{NaCl} ; 5$ $\mathrm{mM} \mathrm{MgCl} 2 ; 100 \mathrm{mM}$ Tris). Adicionar $33 \mathrm{ul} \mathrm{de} \mathrm{BCIP} \mathrm{e} \mathrm{incubar} \mathrm{por} 3 \mathrm{~h}$.

9 - Lavar em PBS adicionado de $20 \mathrm{mM}$ de EDTA.

\subsubsection{2 - Protocolo 2}

1 - Após a corrida do gel de SDS-PAGE, colocar o gel no sistema para transferência em membrana de nitrocelulose, utilizando o Tampão de transferência (24.8 $\mathrm{mM}$ tris; $192 \mathrm{mM}$ glicina; $10 \%$ metanol; ajustar o pH para 8,3 e manter a $4{ }^{0} \mathrm{C}$ ), por $1: 30 \mathrm{~h}$;

2 - A membrana deve ser então corada em solução de vermelho de Ponceau ( $0,5 \%$ Ponceau-S, 1 \% ácido acético, $100 \mathrm{ml}$ de água deionizada) por 10 min e após a confirmação da transferência, lavada em PBS;

3 - Bloquear por $2 \mathrm{~h}$ em tampão de bloqueio (3\% BSA; 0,02 \% azida sódica), sob agitação;

4 - Lavar 5 vezes em solução de PBS e 0,1 \% tween 20, 5 min. cada lavagem;

5 - Incubar com o anticorpo monoclonal na concentração de $50 \mathrm{ug} / \mathrm{ml}$ adicionado de $1 \%$ de NP40 por $1 \mathrm{~h}$;

6 - Lavar com PBS;

7 - Incubar com conjugado anti-camundongo marcado com peroxidase por $1 \mathrm{~h}$.; 
8 - Revelar com $15 \mathrm{mg}$ de 4-cloronaftol dissolvidos em $5 \mathrm{ml}$ de metanol gelado, ao qual se adiciona $20 \mathrm{ml}$ de tampão Tris $(50 \mathrm{mM}) \mathrm{pH}$ 6,8. Adiciona-se ao final $50 \mathrm{ul} \mathrm{de} \mathrm{H}_{2} \mathrm{O}_{2}$ e incubar por 1 hora;

9 - Lavar em água destilada.

\section{7 - Soluções utilizadas}

$$
\begin{aligned}
& \text { PBS - Solução tampão de fosfato } \\
& -8 \mathrm{~g} \mathrm{de} \mathrm{NaCl} \\
& \quad-0,2 \mathrm{~g} \mathrm{de} \mathrm{KCl} \\
& \quad-1,15 \mathrm{~g} \mathrm{de} \mathrm{Na}_{2} \mathrm{HPO}_{4} \\
& \quad-0,2 \mathrm{~g} \text { de } \mathrm{KH}_{2} \mathrm{PO}_{4} \\
& \text { O volume foi completado para } 1 \text { litro com água destilada, e o pH acertado }
\end{aligned}
$$

para $7,36$.

Tampão de Bloqueio - TB1

- PBS

- $1 \%$ de BSA ( Soro Albumina Bovina)

Tampão PBS-T-G

- PBS

$-0,05 \%$ de Tween 20 
$-0,25 \%$ de gelatina

\section{Tampão de OPD}

- 12,15 ml de ácido cítrico 0,4 M

$-25,7 \mathrm{ml} \mathrm{de} \mathrm{Na}_{2} \mathrm{PO}_{4} \quad 0,4 \mathrm{M}$

-300 ul de $\mathrm{H}_{2} \mathrm{O}_{2} 30$ vol.

O volume foi completado para $200 \mathrm{ml}$ com água destilada e o $\mathrm{pH}$ foi acertado para 5,3, ficando armazenado no escuro a $5^{\circ} \mathrm{C}$.

"STOPPER" para OPD

$-\mathrm{H}_{2} \mathrm{SO}_{4} 4 \mathrm{~N}$

$-0,5 \%$ de $\mathrm{Na}_{2} \mathrm{SO}_{3}$

\section{Tampão para PNPP}

$10 \mathrm{mM}$ de dietanolamina

$0,5 \mathrm{mM}$ de $\mathrm{MgCl}_{2}$

Gel separador a $10 \%$ de poliacrilamida

$19,8 \mathrm{ml}$ de acrilamida

$30 \mathrm{ml}$ de tampão "Lower"

$8 \mathrm{ml}$ de água deionizada

$40 \mu \mathrm{l}$ de TEMED $\left(\mathrm{N}, \mathrm{N}, \mathrm{N}^{1}, \mathrm{~N}^{1}\right.$-Tetrametil-etilenodiamina) 
$1 \mathrm{ml}$ de persulfato de amônio a $10 \%$

Gel empilhador a $3 \%$ de poliacrilamida

$2 \mathrm{ml}$ de acrilamida

$10 \mathrm{ml}$ de tampão "Upper"

$7 \mathrm{ml}$ de água deionizada

$40 \mu l$ de TEMED

$600 \mu \mathrm{l}$ de persulfato de amônio a $10 \%$

\section{Solução Fixadora para coloração com prata}

40\% de Etanol P.A.

10\% de Ácido Acético

Preparada em água deionizada.

\section{Solução Incubadora para coloração com prata}

$17 \mathrm{~g}$ de Acetato de Sódio $3 \mathrm{H}_{2} \mathrm{O}$

$75 \mathrm{ml}$ de etanol $96^{\circ}$ GL P.A.

$1 \mathrm{~g}$ de Tiossulfato de Sódio

$1,3 \mathrm{ml}$ de Glutaraldeído a 25\% (Adicionar somente na hora do uso).

O volume foi completado para $250 \mathrm{ml}$ com água deionizada.

\section{Solução de prata}

0,25 g de Nitrato de Prata 
$50 \mu \mathrm{l}$ de Formaldeído

O volume foi completado para $250 \mathrm{ml}$ com água deionizada.

\section{Solução Reveladora}

6,25 g de Carbonato de Sódio

$25 \mu l$ de Formaldeído

O volume foi completado para $250 \mathrm{ml}$ com água deionizada.

\section{Solução "STOP" para coloração com prata}

\section{3,65 g de Sódio EDTA $2 \mathrm{H}_{2} \mathrm{O}$}

O volume foi completado para $250 \mathrm{ml}$ com água deionizada.

Obs: É importante manter o volume de $250 \mathrm{ml}$ para gel de $1 \mathrm{~mm}$, pois a redução deste volume interfere na nitidez da coloração.

\section{8 - Meios de cultura utilizados}

\section{Meio Básico RPMI - 1640}

O meio RPMI-1640 (sem bicarbonato, contendo L-glutamina) (1 pacote por litro) foi dissolvido em água mili-Q, acrescentando:

$-2,0 \mathrm{~g}$ de $\mathrm{NaHCO}_{3}$

- 5,96 g de HEPES (p.m. 238,3) 
- $40 \mathrm{mg}$ de gentamicina

- $\beta$ - mercaptanol na concentração final de $5 * 10^{-5} \mathrm{M}$.

$\mathrm{O} \mathrm{pH}$ foi ajustado para 7,2 - 7,4 com $\mathrm{HCl}$ ou $\mathrm{NaOH}$ e o volume foi completado para 1 litro. $\mathrm{O}$ meio foi filtrado em um sistema Millipore (filtro de 0,22 mm) para esterilização, utilizando vácuo de 5 psi.

\section{Meio R10}

- $10 \mathrm{ml} \mathrm{de} \mathrm{soro} \mathrm{fetal} \mathrm{bovino} \mathrm{(SB)}$

- $90 \mathrm{ml}$ de RPMI-1640

O SFB foi previamente inativado por 30 minutos a $56^{\circ} \mathrm{C}$ e fracionado em alíquotas de $50 \mathrm{ml}$, sendo conservado em freezer $-20^{\circ} \mathrm{C}$. No caso de meio R20, adiciona-se $20 \%$ de soro fetal bovino.

\section{Preparo do PEG}

O PEG (Polyethilenoglycol - p.m. 3000 - 3700) foi colocado em banho-maria a $56^{\circ} \mathrm{C}$, até que se tornasse totalmente liqüefeito. Com uma seringa esterilizada foram adicionados 2 $\mathrm{ml}$ de RPMI-1640 e $200 \mathrm{ml}$ de DMSO. Esta mistura foi deixada a $37^{\circ} \mathrm{C}$ e antes de sua utilização, foi checado o pH da solução resultante (que deve estar entre 7,0 e 7,5) A solução de PEG foi então aliquotada em tubos de $1,5 \mathrm{ml}$ contendo $1 \mathrm{ml}$ da solução.

\section{Meio HAT}

$-20 \mathrm{ml} \mathrm{de} \mathrm{SFB}$ 
- 2 ml de HAT 50 X concentrado em $10 \mathrm{ml}$ de meio RPMI-1640

- $78 \mathrm{ml}$ de RPMI-1640

\section{Meio de Congelamento}

$-4 \mathrm{ml} \mathrm{de} \mathrm{SFB}$

- $4 \mathrm{ml}$ de RPMI- 1640

$-2 \mathrm{ml}$ de DMSO

\section{Meio HT 20\%}

- $2 \mathrm{ml}$ de HT 50 X concentrado em $10 \mathrm{ml}$ de RPMI-1640

$-20 \mathrm{ml}$ de soro fetal bovino

- $\quad 178 \mathrm{ml}$ de RPMI-1640 


\section{3- RESULTADOS E DISCUSSÃO}

De acordo com os objetivos propostos para este trabalho, anticorpos monoclonais e policlonais foram produzidos contra o ToMV e estes anticorpos apresentaram maior especificidade na identificação do tobamovírus, sem mostrar reação cruzada com extratos celulares .

Plantas de tomate infectadas com o ToMV foram coletadas em campos de produção comercial próximos à àreas de produção de mudas e também foram utilizadas em ensaios com os anticorpos e para re-isolamento do tobamovírus e, posterior re-inoculação em plantas de tabaco (Nicotiana tabacum "Turkish NN" e Nicotiana rustica) e de tomate (Lycopersicon esculentum Mill.), promovendo assim a confirmação dos sintomas.

Na quase totalidade dos ensaios, o TMV foi testado juntamente com o ToMV para garantir a baixa reatividade cruzada que os anticorpos produzidos apresentaram. A caracterização dos MAbs e dos anticorpos policlonais também foi realizada, através de isotipagem e de ensaios imunoenzimáticos. Os resultados obtidos apresentam-se abaixo. 


\section{1 - Obtenção dos anticorpos monoclonais e policlonais}

Dos camundongos imunizados, como mostra os resultados de D.O. a 492nm, na Figura 7 das quatro imunizações, o camundongo 3 foi escolhido para ter seu baço retirado para a fusão. Foram obtidos cerca de 123 hibridomas das 10 placas de fusão, dos quais, oito colônias “mães" foram selecionadas e congeladas . A colônia denominada 10 H1 foi escolhida para clonagem por apresentar melhor título em ELISA e não apresentar reação cruzada com TMV. Das 10 placas de clonagem, foram escolhidos 5 , colônias que apresentaram alta reação com o ToMV e baixa reação cruzada com TMV, além de apresentarem bom crescimento nas placas de 24 orificios e posteriormente nas garrafas de $25 \mathrm{~cm}^{2}$. As colônias foram: 10H1H1, 10H1B9, 8G7D4, 8G1B2, 3B8A8 e 10H6D6, respectivamente (Figura 8) . Estes clones foram expandidos e congelados, enquanto estavam sendo testados.

$\mathrm{O}$ melhor clone, $10 \mathrm{H} 1 \mathrm{H} 1$ foi multiplicado e reclonado, sendo escolhido o clone $6 \mathrm{H} 9$ para ser multiplicado via ascite (Harlow \& Lane, 1988). Para facilitar a marcação, foi adotado a nomenclatura de $10 . \mathrm{H} 1$ para este clone. 


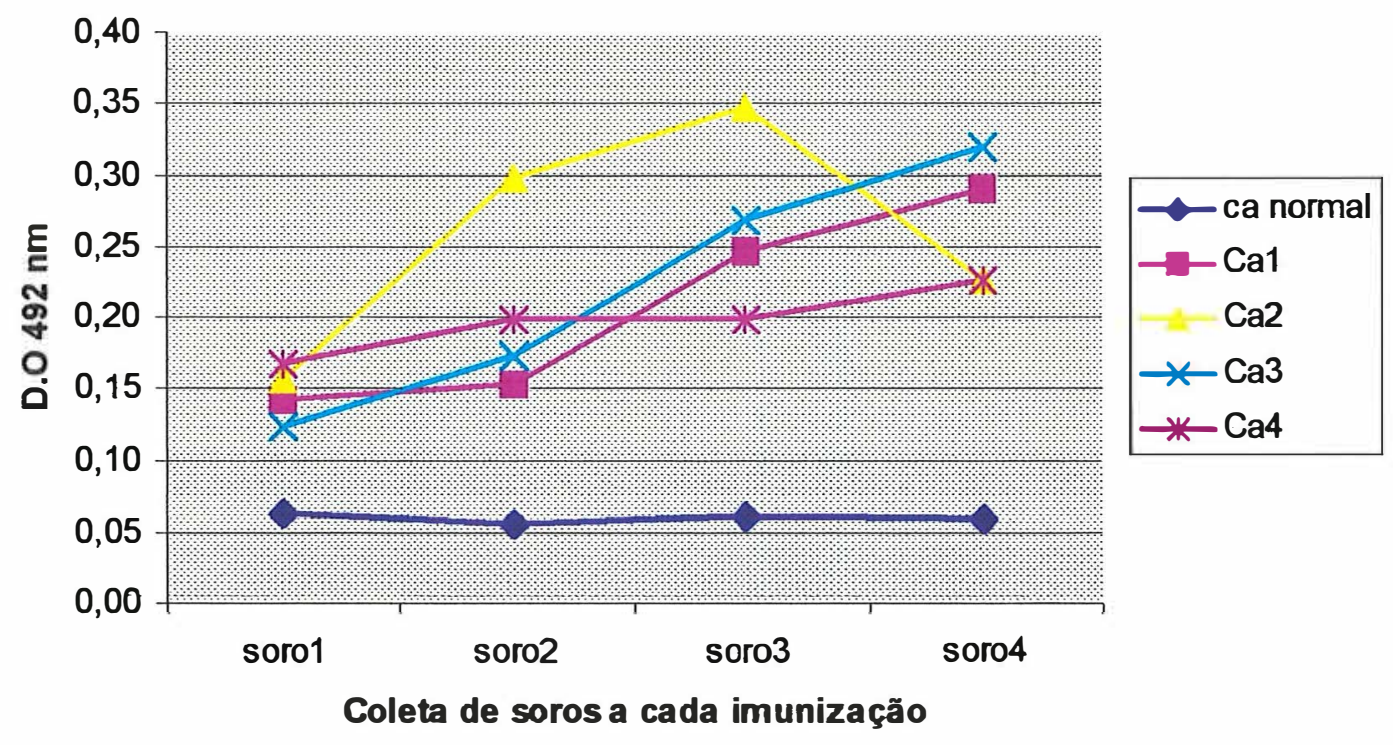

Figura 7 - Titulação dos soros dos camundongos imunizados a intervalos de 20 dias, onde foram coletados os soros $1,2,3$ e 4 respectivamente. Cada curva representa resultados do ELISA realizado com soro na diluição de 1:200 dos quatro animais e do camundongo normal, usado como controle.

A escolha do camundongo 3 fez-se pela melhor resposta às imunizações dadas, podendo ser neste caso também utilizado o camundongo 1 . Geralmente os títulos se incrementam a cada nova imunização, mas há casos onde ocorre um decréscimo do título devido ao desenvolvimento de tolerância imunológica, como podemos observar no camundongo 2 (Figura 7) (Iturbe, 1988; Perez, 1991). 


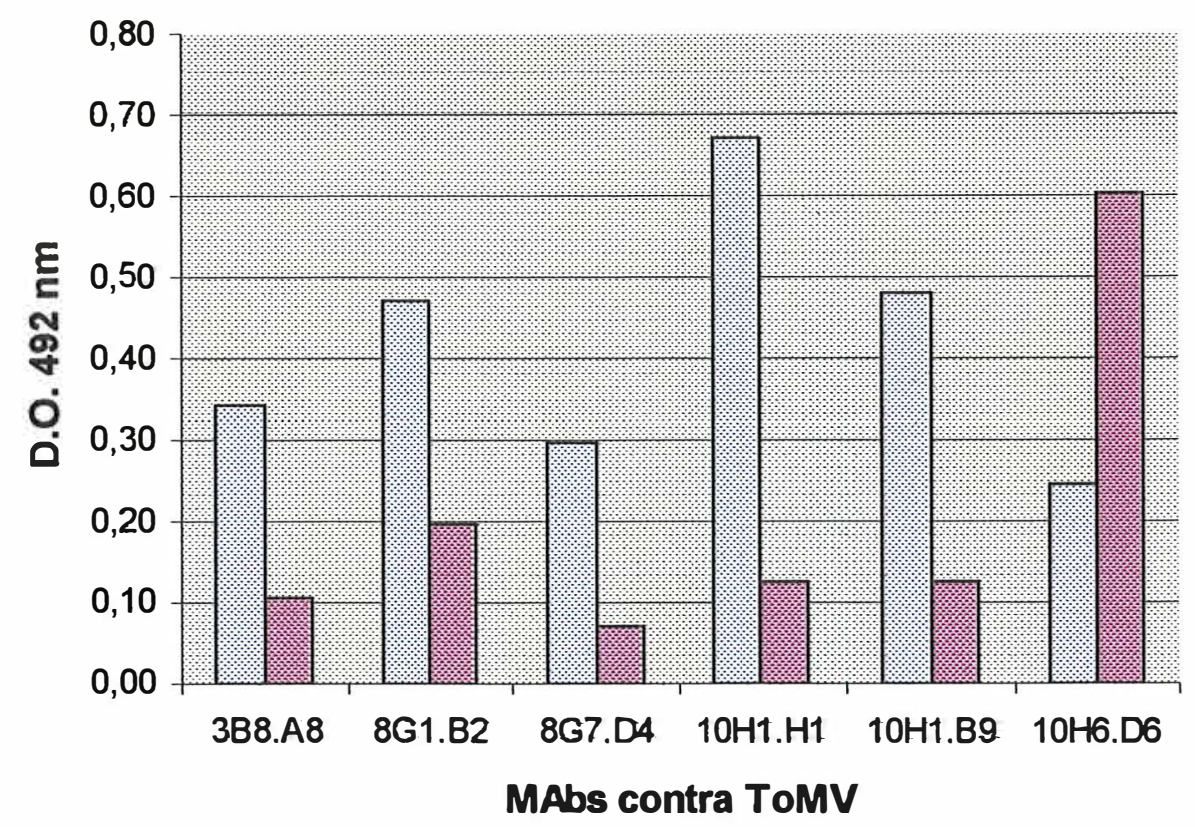

\section{圈 TOMN \\ 凅 TMN}

Figura 8 - Resultados da titulação dos anticorpos monoclonais selecionados contra o ToMV, utilizando 100 ul de sobrenadante de cultura, em ensaio do tipo ELISA indireto utilizando o TMV e o ToMV como antígenos.

Os anticorpos policlonais produzidos em coelho foram armazenados em freezer -20 ${ }^{0} \mathrm{C}$ para posterior purificação e quantificação. 


\section{2 - Caracterização dos anticorpos monoclonais e policlonais produzidos}

\subsection{1 - Isotipagem}

A isotipagem foi realizada com os seis anticorpos monoclonais e todos os clones puderam ser isotipados. A vantagem do uso deste Kit é a facilidade de utilização aliado à rapidez dos resultados. Neste ensaio, os MAbs 10H1.H1, 10H1.B9, 8G7.D4 e 8G1.B2 apresentaram títulos positivos para a IgG2a, comparados com o controle positivo do Kit, enquanto que os MAbs 3H8.A8 e 10H6.D6 apresentaram título para o isotipo IgG2b. Todos os MAbs foram caracterizados com cadeia leve do tipo Kappa, bastante comum em camundongos (Roitt et al., 1992 ).

\subsection{2- Resultado da Purificação dos tobamovírus TMV e ToMV}

Esta purificação do TMV foi realizada no Laboratório de Virologia, do Depto. de Fitopatologia, Entomologia e Zoologia (ESALQ/USP) e a suspensão de tobamovírus obtida foi armazenada em alíquotas de $100 \mathrm{mg} / \mathrm{ml}$ de tampão PBS, com uma pureza de $83 \%$, suficiente para ser utilizado nos ensaios. Na purificação do ToMV foram obtidos $0,79 \mathrm{mg}$ do vírus/100 $\mathrm{g}$ de folha de tabaco, que foram armazenados em alíquotas de $200 \mathrm{ug} / \mathrm{ml}, \mathrm{a}-20{ }^{\circ} \mathrm{C}$. 


\subsection{3 - Ensaio de Competição}

No ensaio de competição utilizando soro policlonal de coelho e o MAb 10.H1 expandido via ascite foi possível fazer uma avaliação dos epitopos inespecíficos do antígeno que vão se ligar ao soro policlonal, restando somente os sítios específicos encontrados no anticorpo monoclonal, apresentando assim uma competição por sítios mais ou menos específicos do antígeno (Gesztesi et al., 1996). O anticorpo monoclonal está representado por "ascite", como ilustra a Figura 9.

Neste ensaio é possível verificar que os epitopos reconhecidos pelos anticorpos monoclonais e policlonais não são totalmente iguais, pois há diferenças nas curvas de titulação dos anticorpos policlonais em relação ao MAb (Harlow \& Lane, 1988). A especificidade do MAb em relação ao soro policlonal aumenta quanto maior é a concentração do anticorpo policlonal, mostrando assim que a inespecificidade do soro policlonal é proporcional à concentração de IgG que é utilizada. A diferença entre a curva do Ascite (MAb 10.H1) e do ascite + soro deve-se à competição por sítios que os anticorpos apresentam.

\subsection{4- Ensaio de Reatividade do ToMV e Utilização do Tampão de Bloqueio ao longo do tempo}

Os resultados da reatividade do vírus ao longo do tempo, em placa podem ser visualizados na Figura 10. O uso do tampão de bloqueio mostrou-se necessário, uma 
vez que os resultados mostraram que as placas que não recebiam o tampão apresentaram ligações inespecíficas, pois as leituras feitas no leitor de Placas, com D.O. a $405 \mathrm{~nm}$ superaram o limite de leitura espectrofotométrica de 3.500 .

Este ensaio foi idealizado com duas finalidades: primeiro mostrar que uma placa já sensibilizada pode apresentar resultados semelhantes no ELISA mesmo guardada à temperatura ambiente por cerca de 25 dias e, a necessidade de se utilizar o tampão de bloqueio, que é composto de BSA, o que encarece bastante a reação e poderia ser eliminado uma vez que os resultados não apresentassem diferenças, o que não foi verificado.

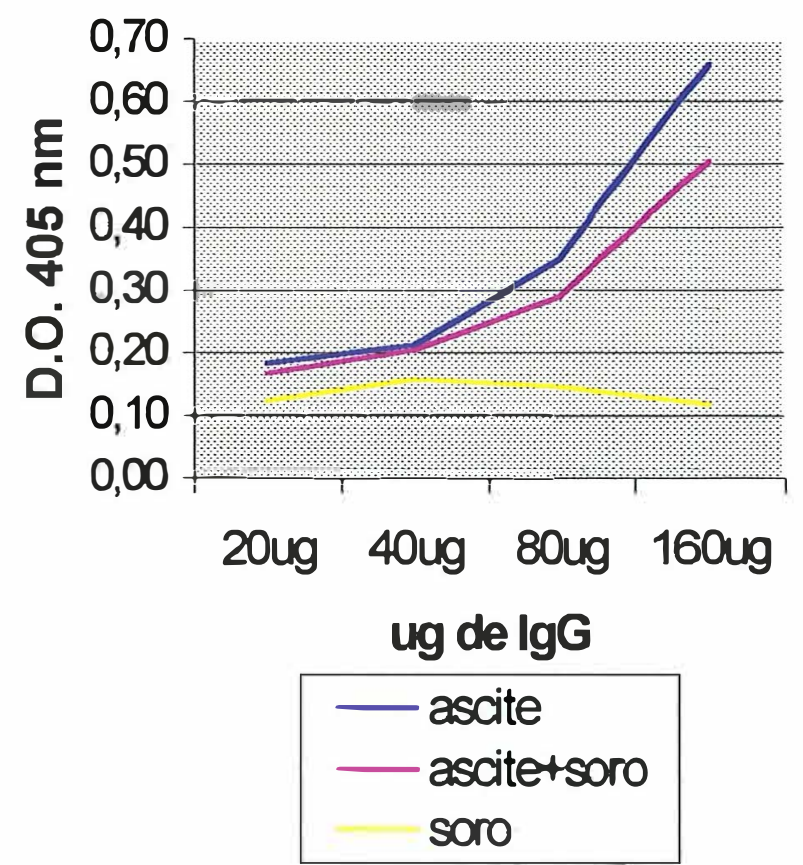

Figura 9 - Ensaio de ELISA, mostrando a competição do anticorpo monoclonal 10.H1(ascite) e soro policlonal de coelho, ambos contra TQMV. 


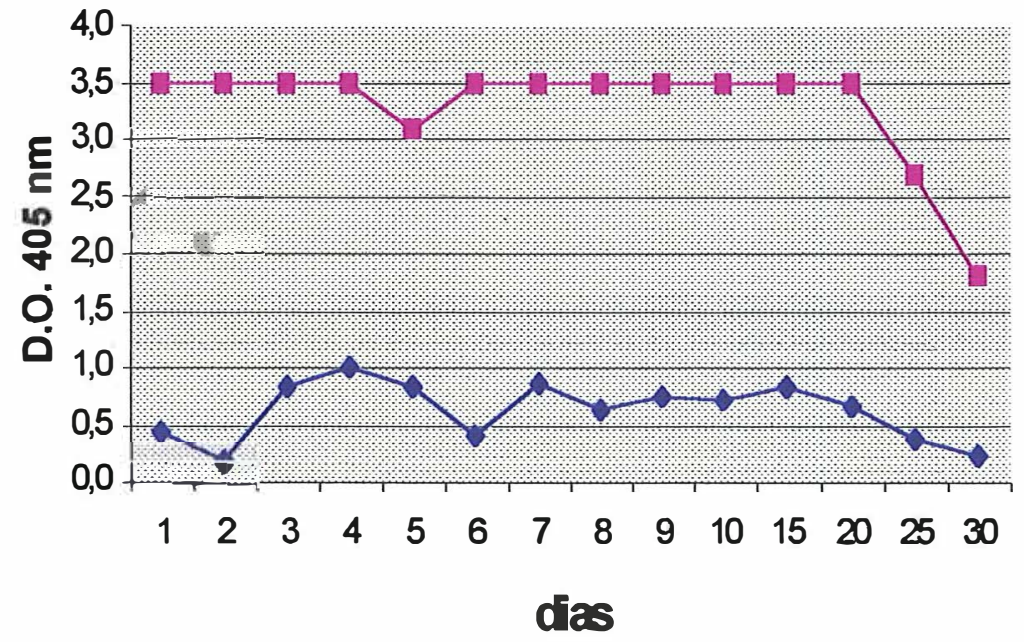

$$
\begin{aligned}
& \rightarrow \text { bloqueado } \\
& \rightarrow-\text { não bloqueado }
\end{aligned}
$$

Figura 10 - Gráfico de reatividade do ToMV em testes de ELISA ao longo do tempo, com e sem tampão de bloqueio. 


\subsection{5 - Ensaio com Plantas Infectadas}

Os resultados, visualizados na Figura 11 mostram que em diluições maiores, a reação inespecífica da planta sadia iguala-se a reação da planta infectada com o TMV, mostrando que o clone 10.H1 apresenta especificidade no reconhecimento do ToMV.

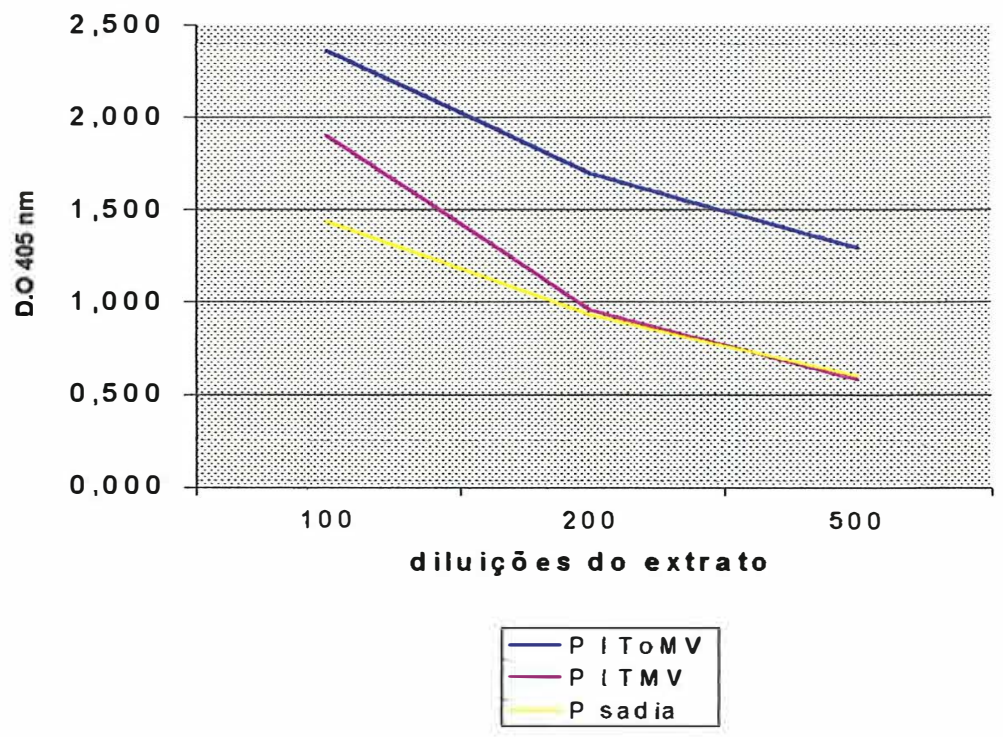

Figura 11 - Ensaio utilizando plantas infectadas com TMV, plantas infectadas com ToMV e planta sadia em ELISA com ascite do MAb $10 . \mathrm{H} 1$ na concentração de $50 \mathrm{ug} / \mathrm{ml}$ de IgG, onde os extratos de plantas foram diluídos em PBS 100 vezes, 200 vezes e 500 vezes. 


\subsection{6 -Ensaio com as Amostras Coletadas}

Neste ensaio do tipo ELISA indireto foram utilizados amostras coletadas no campo reagindo contra o MAb 10.H1, produzido contra o ToMV (Figura 12).

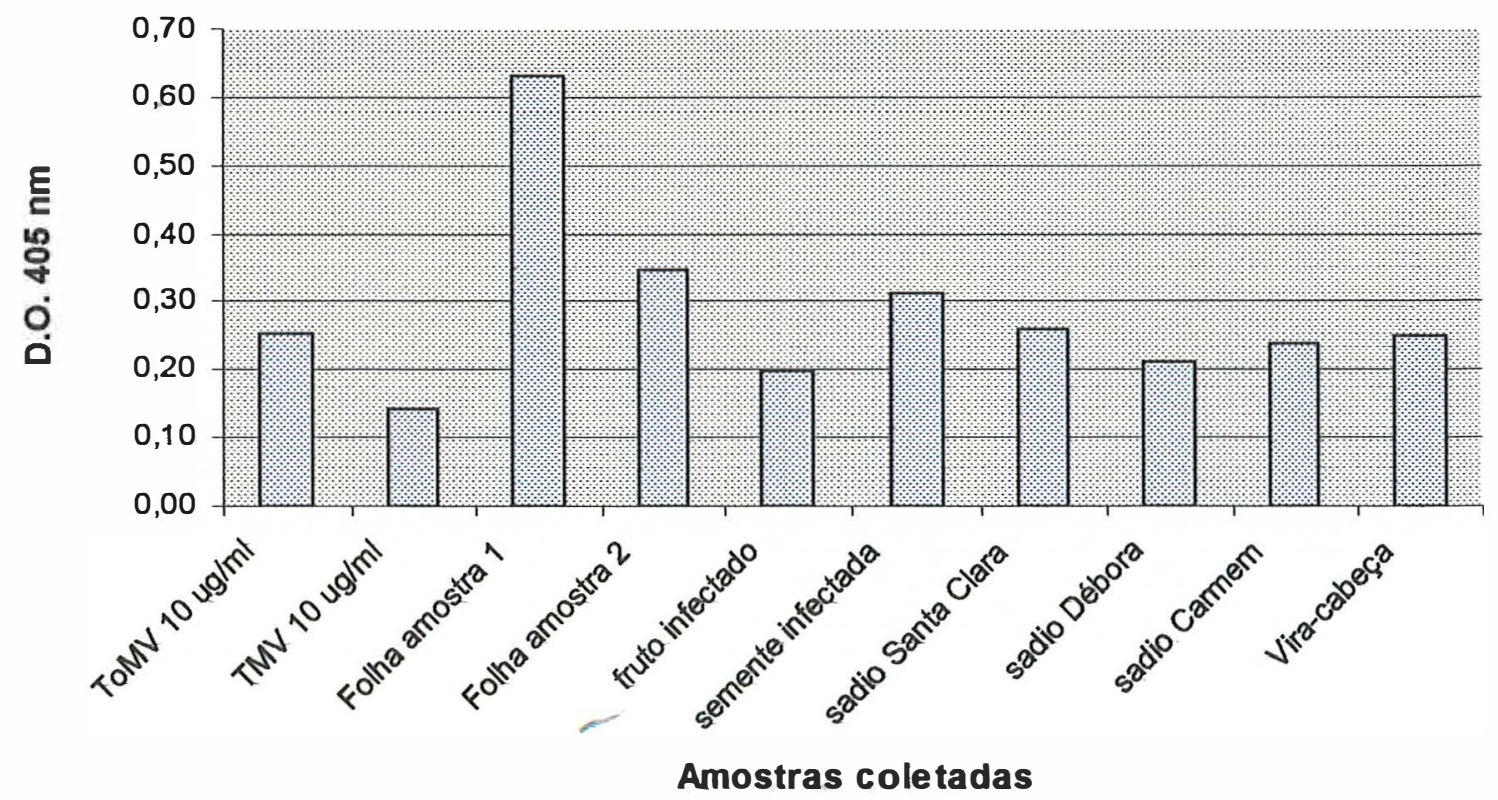

Figura 12 - ELISA de amostras retiradas do campo contendo sintomas de ToMV, comparado com plantas sadias, plantas com sintomas de TMV e do complexo Vira-cabeça. As amostras foram maceradas e diluídas 100 vezes em PBS.

4.2.7 - Resultados do Teste Biológico em Plantas de Tomate e de Tabaco 
As plantas de tomate inoculadas com o ToMV isolado de tabaco mostraram sintomas bastante severos, levando algumas plantas a definharem completamente e outras a exibirem sintomas bastante característicos de afilamento de folíolos e mau desenvolvimento das plantas. Tal procedimento é recomendado quando se deseja certeza na avaliação dos sintomas observados em campo, tornando assim o diagnóstico confiável (Mattheus, 1992).

Além da literatura descrevendo os sintomas típicos, nossas inoculações apresentaram resultados semelhantes aos obtidos por Weber \& Pfitzner (1998), que obtiveram o mesmo sintoma de afilamento acentuado nas folhas de tomate infectado (Figuras 13 e 14).

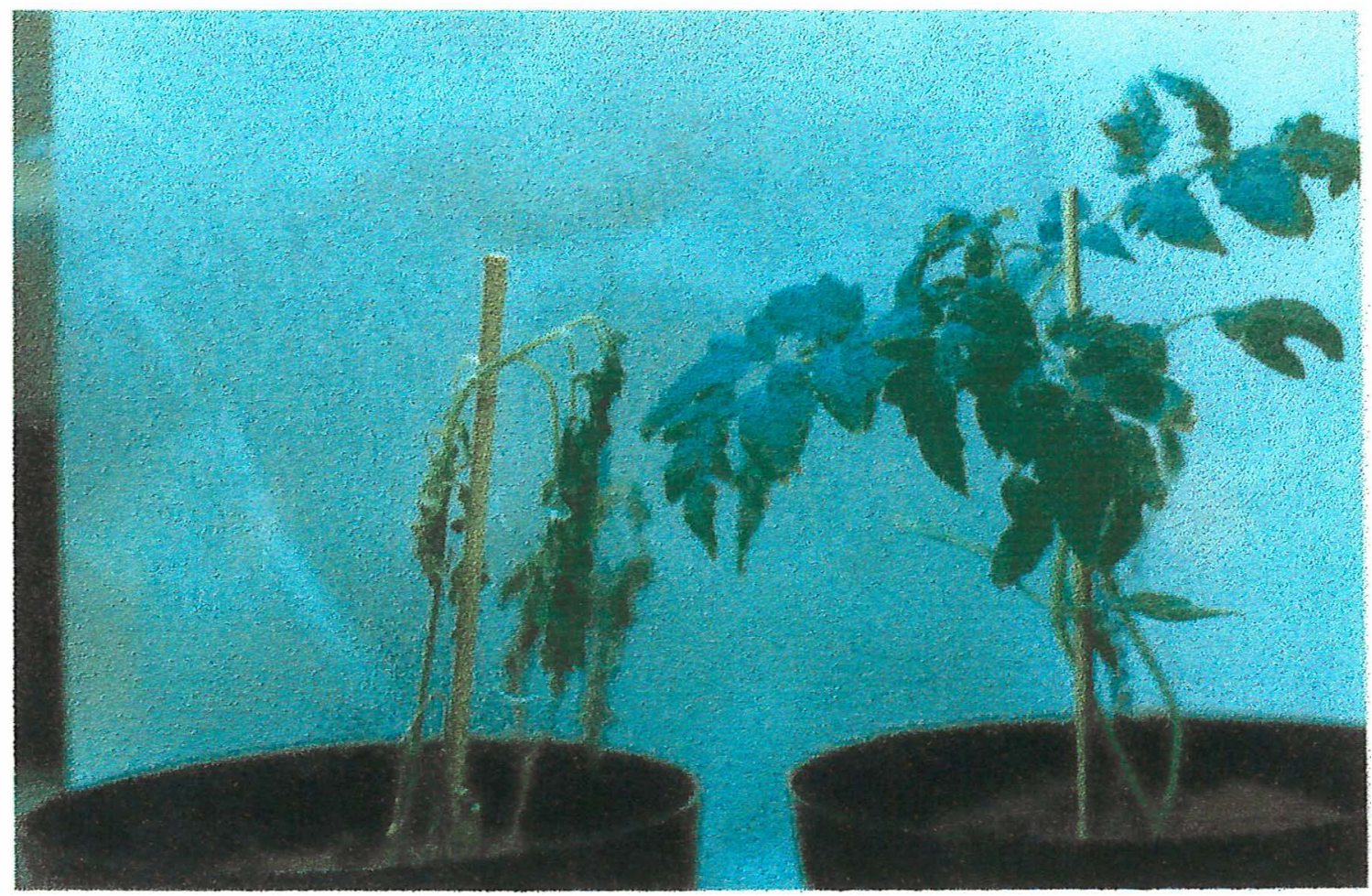

Figura 13 - Sintomas severos do ToMV em planta de tomate var. Santa Clara (a esquerda), em comparação com a planta sadia (a direita). 


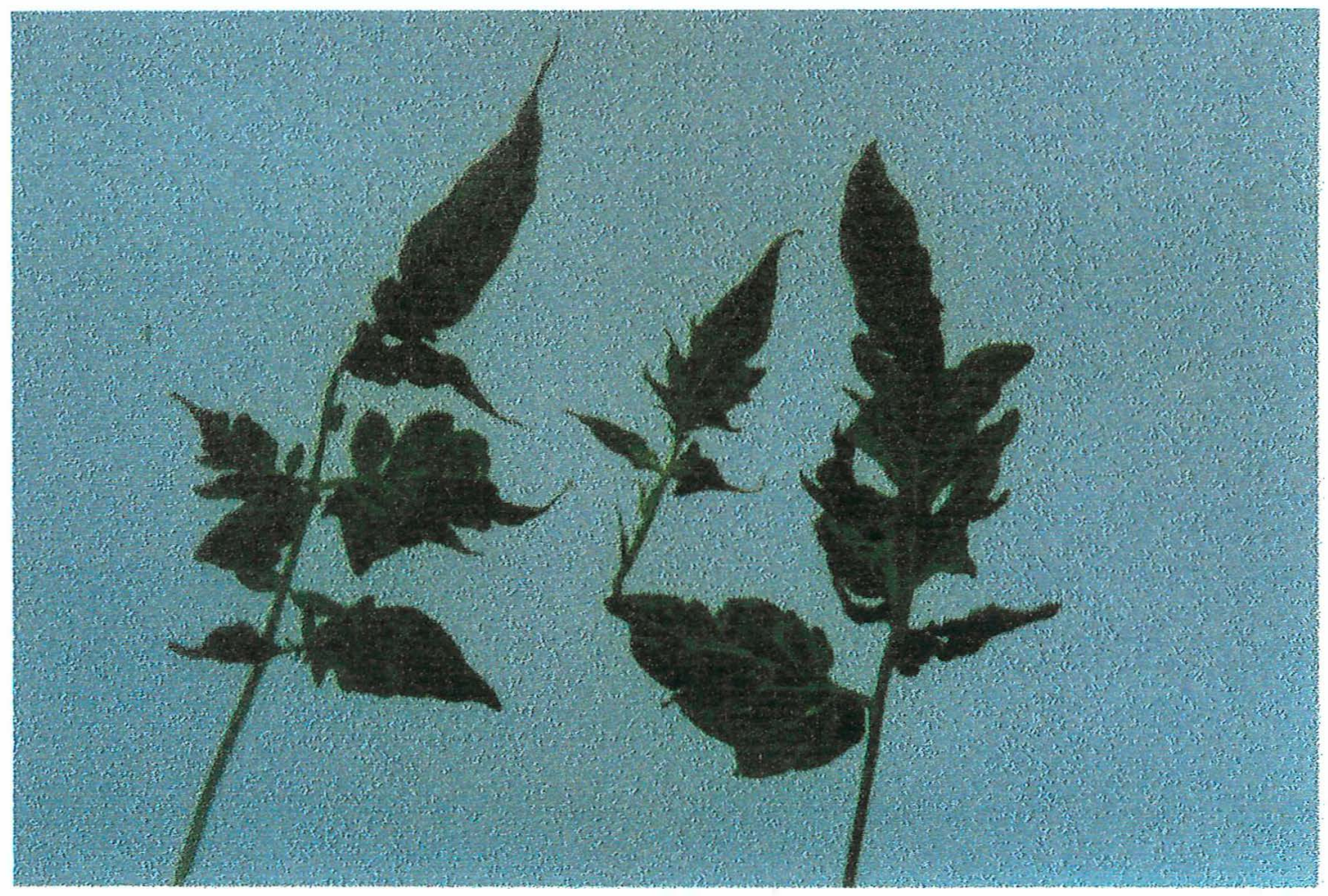

Figura 14 - Sintoma típico de afilamento e deformação dos folíolos do tomateiro causada pela inoculação do ToMV. Na foto, todos os folíolos apresentam-se deformados.

$\mathrm{Na}$ inoculação de plantas de tabaco com o ToMV, as folhas exibiram sintomas típicos de lesão local. Conforme descrito em Mattheus (1993), onde o uso de diferentes variedades de tabaco produzem diferentes tipos de lesão, dependendo do vírus inoculado, que neste caso foi utilizada a variedade de tabaco Nicotiana tabacum "Turkish 
NN', destinada a produzir lesões locais quando inoculada por ToMV, como pode ser visto na Figura 15.

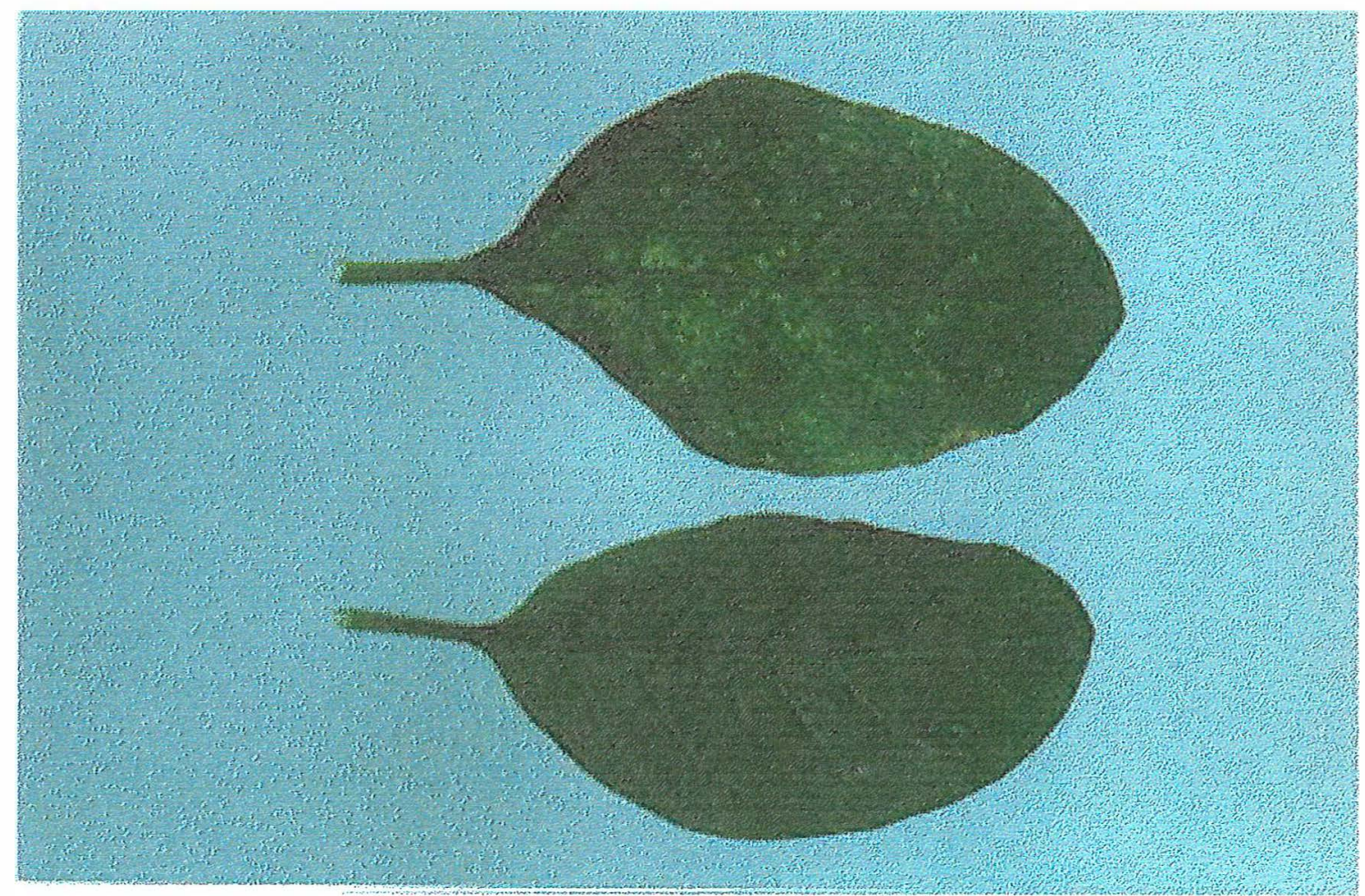

Figura 15 - Folha de tabaco ( $N$. rustica) exibindo sintomas locais devido à inoculação com ToMV (folha de cima), comparado com folha sadia (folha que está abaixo). 


\subsection{8 - Eletroforese de proteínas totais - SDS-PAGE}

Como pode ser visto na Figura 16, no gel corado com prata, as amostras extraídas do vírus não puderam ser observadas nas canaletas 2 e 3 do gel, contudo nas canaletas 4,5 e 6 aparecem bandas das plantas maceradas e do vírus que infectava-as, o que não aparece na canaleta 7 (banda de $20 \mathrm{kDa}$ aproximadamente) onde foi colocada extrato de planta sadia de tabaco. A utilização do SDS-PAGE em conjunto com imunoensaios tem sido bastante realizada por se tratar de m passo intermediário para o imuno blot (Scarmam et al., 1998). 


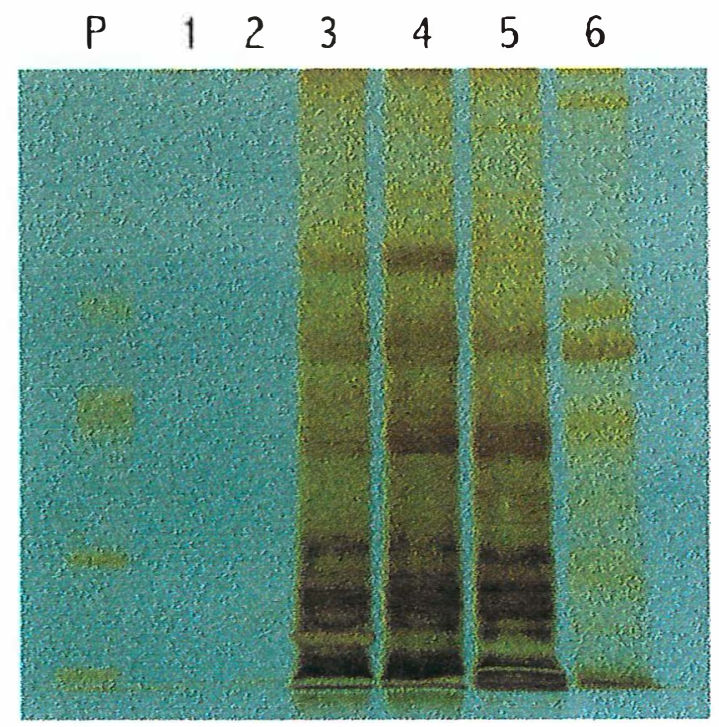

Figura 16 - Gel de SDS-PAGE corado com Prata onde se vê, da esquerda para a direita: P padrão de peso molecular, 1 - ToMV macerado uma vez; 2 - ToMV macerado duas vezes; 3 - Fruto de tomate infectado com ToMV; 4 - Planta de tomate infectada com ToMV; 5 Planta de tabaco infectada com ToMV e 6 - Planta de tabaco sadia. 


\subsection{9 - Imuno Blot}

Neste ensaio, o MAb 10.H1 e o soro policlonal produzido em coelhos foram utilizados para atestar a presença das bandas referentes ao tobamovírus após corridas em gel de eletroforese de proteínas totais, onde a banda referente ao vírus não aparece na canaleta em que o ToMV ou o TMV correm sozinhos (Figura 16).

Neste experimento, uma réplica do gel da Figura 17 foi transferido para a membrana de nitrocelulose e revelada com o anticorpo policlonal (Figura 18) onde vemos as duas bandas de peso aproximado de $20 \mathrm{kDa}$ e de $30 \mathrm{kDA}$, que segundo a literatura (Mattheus,1992; Ohno et al., 1984) corresponde à banda da capa protéica do ToMV de 17,5 $\mathrm{kDa}$ (a banda mais abaixo) e a banda (2) à proteína requerida para o movimento célula-acélula, de $30 \mathrm{kDa}$. Ambas as bandas aparecem nos extratos de planta de tomate infectado e no tabaco infectado. Na Figura 19, o imuno blot foi feito com o anticorpo monoclonal 10.H1 e aparece apenas a banda referente à proteína da capa protéica do ToMV de 17,5 $\mathrm{kDa}$. 


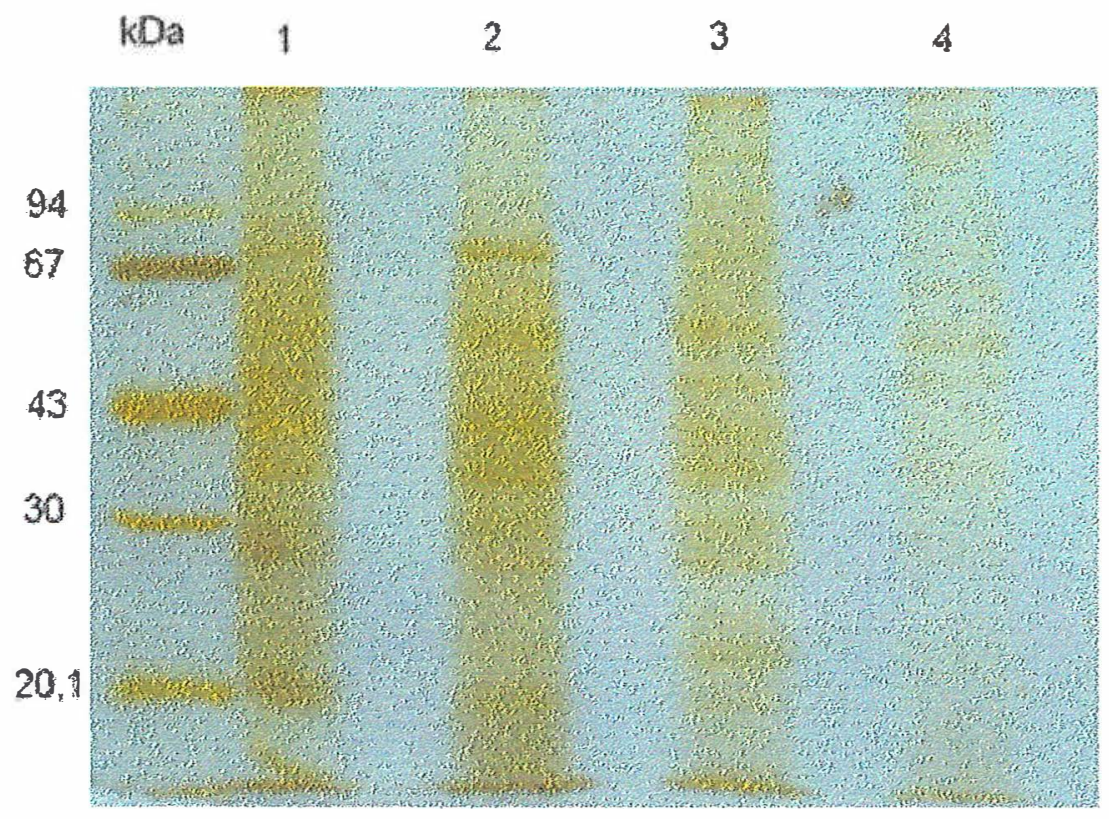

Figura 17 - Gel de eletroforese de proteínas totais corado com prata onde temos o padrão de peso molecular em $\mathrm{kDa}$, canaleta 1: plantas de tomate com ToMV; 2: planta de tomate sadia; 3: planta de tabaco com ToMV; 4: planta de tabaco sadia. 


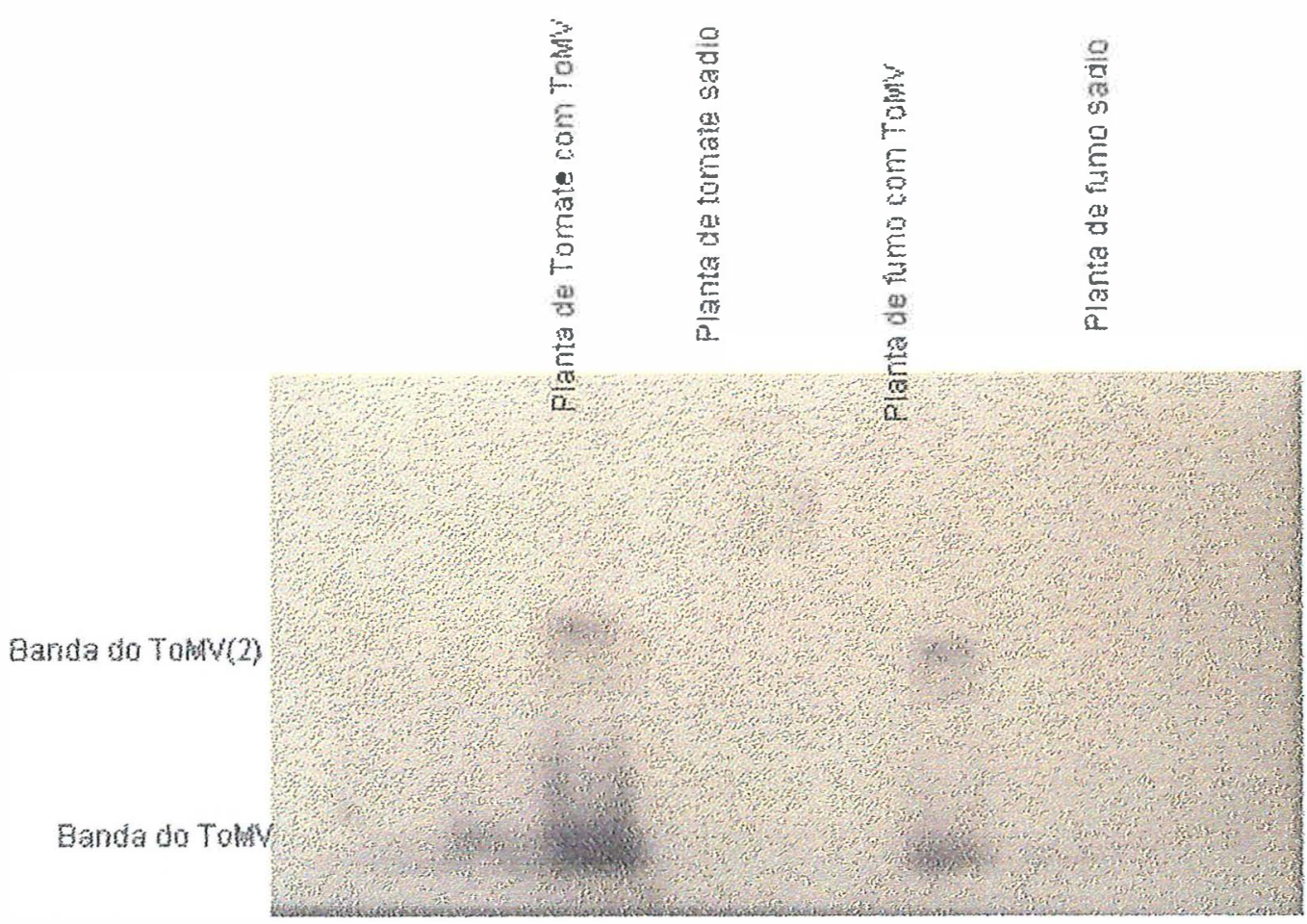

Figura 18 - Imuno Blot mostrando as duas bandas reconhecidas pelo anticorpo policlonal produzido em coelho, contra o ToMV, nas plantas de tomate infectado (primeira canaleta da esquerda para direita) e em fumo infectado (terceira canaleta, também da esquerda para a direita). Esta membrana de nitrocelulose foi revelada com NBT/BCIP. 


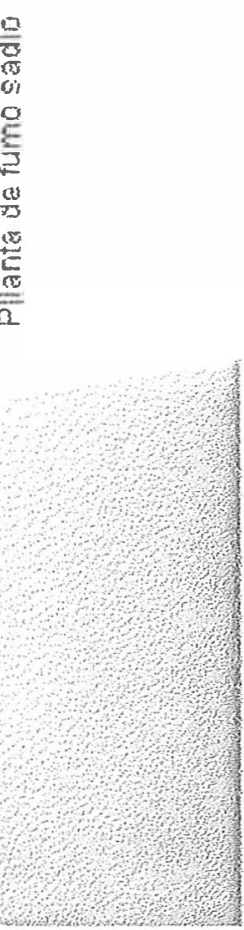

Figura 19 - Imuno Blot utilizando o MAb 10.H1, revelado com 4cloronaftol, onde vemos apenas uma banda referente à capa protéica do ToMV.

A proteína de $17,5 \mathrm{kDa}$, além de ser parte estrutural dos tobamovírus, ela influencia na doença, determinando se a lesão será necrótica local ou sistêmica, como também pode determinar, pela sua constituição de aminoácidos, as plantas resistentes. A 
proteína de $30 \mathrm{kDa}$ é responsável pelo movimento célula-a-célula, envolvida no movimento através dos plasmodesmos (Mattheus, 1992.). Resultados semelhantes foram obtidos em imuno blot de tobamovírus por Hamamoto et al. (1997), porém utilizando fragmentos das proteínas isoladas por RT-PCR .

A escolha dos testes de ELISA neste trabalho se deu pelo fato do ELISA ser bastante rápido (Coyne et al., 1996) e apresentar alta sensibilidade e alta especificidade quando se trata de diagnóstico de doenças (Crowther, 1995). Embora os estudos recentes de vírus da plantas apontem para técnicas como PCR e RT-PCR e "fingerprinting" (Joelson et al., 1997; Jacobi et al., 1998), inclusive para a identificação do ToMV (Routh et al., 1997). trabalhos caracterizando o ToMV e o TMV tem sido realizados utilizando somente imunoensaios (Bachand \& Castello, 1998).

Como principal vantagem está o fato de que uma vez estabelecido o ensaio, um técnico de nível médio é perfeitamente capaz de realizar os ELISAs e analisar os dados, uma vez que se trata de uma reação colorimétrica de resultados visuais. Já o PCR e técnicas afins necessitam, depois de estabelecido o teste, de pessoal especializado principalmente para a análise dos resultados. Neste trabalho nos propusemos a produzir os anticorpos monoclonais e realizar testes com amostras do campo infectadas com o ToMV, mostrando que é possível, a partir destes resultados produzir um "kit" destinado a agricultores e produtores de mudas de tomate. 


\section{5 - CONCLUSÕES}

De acordo com os objetivos propostos, neste trabalho foi possível produzir anticorpos policlonais e anticorpos monoclonais contra o ToMV, dentre os quais o MAb 10.H1, pertencente à classe IgG2a, Kappa, apresentou maior título e maior especificidade no diagnóstico do ToMV, sendo portanto escolhido.

Este MAb apresentou-se bastante eficiente no diagnóstico da doença in vivo, sem mostrar reação cruzada com o TMV e com os extratos celulares. Sua sensibilidade e precisão puderam ser avaliadas através de Imuno Blot, onde uma única banda relativa à capa protéica do tobamovírus foi identificada. 
Uma vez que os ensaios foram padronizados e os testes em plantas confirmados, o MAb $10 . \mathrm{H} 1$ poderá ser utilizado na construção de um kit destinado a agricultores e produtores de mudas de tomate. 


\section{6 - BIBLIOGRAFIA CITADA}

ADAM, G.; ROGGERO, P.; MALAVASI, F.; MILNE, R.G.; PAPA, G. Approach to a general tospovirus assay using antibodies to purified tomato spotted wilt tospovirus G proteins. In: EPPO conference on new methods of diagnosis in plant protection, Wageningen, Netherlands. Bulletin-OEPP, v.25, n.1-2, p. 247-257, 1995.

AGRIANUAL - 1999, p.516, 2000.

AL MOUDALAAL, Z.; ALSCHUH, D.; BRIAND, J. P.; VAN REGENMORTEL, M. H. V. Comparative sensitivity of different ELISA proceedures for detecting monoclonal antibodies. Journal of Immunological Methods, v. 68, p. 35-43, 1984. 
ALONSO, I.X.; MEJIAS, Y. Presencia de los virus del mosaico del tomate, mosaico del pepino y mosaico del melon de agua en plantas de vicaria (Catharanthus roseus). Proteccion de plantas, v.2, n.3, p.93-96, 1992.

ALTSCHUH, D.; HARTMAN, D.; REINBOLT, J.; VAN REGENMORTEL, M. H. $\mathrm{V}$. Immunochemical studies of tobacco mosaic virus - V : localization of five epitopes in the protein subunit by inhibition tests with synthetic peptides and cleavage peptides from three strains. Molecular Immunology, v. 20, n.3, p. 271-8, 1984.

BACHAND, G.D.; CASTELLO, J.D. Seasonal Pattern of tomato mosaic tobamovirus infection and concentration in Red Spruce Seedlings. Applied and Environmental Microbiology, v.64, n.4, p.1436-1441, 1998.

BASTOS, H.B. Tobamovírus do mosaico do tomaterio: levantamento, identificação, caracterização de estirpes em algumas regiões do estado de São Paulo e determinação da herança da resistência. Botucatu, 1998, 58 p. Dissertação (Mestrado) - Campus de Botucatu - UNESP.

BERGAMIN FILHO, A.; KIMATI, H.; AMORIN, L.; CAMARGO, L.E.A.; REZENDE, J.A.M. Manual de Fitopatologia. $3^{\circ}$. ed., São Paulo, Ed. Agronômica Ceres, 1995. 774p. 
BOS, L. Introduction to Plant Virology, London, Longman, 1983. 160p.

CAMPBELL, A.M. Monoclonal antibody technology: the producton and characterization of rodent and human hibridomas. In: BURDON, R.H.; KNIPPENBERG, P.H. VAN. Laboratory Techniques in Biochemistry and Molecular Biology. Amsterdam, Elsevier, 1984, v.13, 231 p.

CANDRESSE, T.; CAMBRA, M.; DALLOT, S.; LANNEAU, M.; ASENSIO, M.; GORRIS, M.T.; REVERS, F.; MACQUAIRE, G.; OEMOS, A.; BOSCIA, D.; QUIOT, J.B.; DUNEZ, J. Comparison of monoclonal antibodies and polymerase chain reaction assays for the typing of isolates belonging to the $\mathrm{D}$ and M serotypes of plum pox potyvirus. Phytopathology, v.88, n.3, p.198-204, 1998.

CANER, J.; COLARICCIO, A.; CHAGAS, C.M.; ALBA, A.P.C.; VICENTE, M. Identificação de um isolado do tobamovírus do mosaico do tomateiro (ToMV) no estado de São Paulo. Fitopatologia Brasileira, v.15, n.4, p. 347-350, 1990.

CASTELLO, J.D.; LAKSHMAN, D.K.; TAVANTZIS, S.M.; ROGERS, S.O.; BACHND, G.D.; JAGELS, R.; CARLISLE, J.; LIU, Y. Detection of infectious tomato mosaic virus in fog and clouds. Phytopathology, v.85, n.11, p.14091412, 1995. 
CEROVSKÁ, N. production of monoclonal antibodies to potato virus $\mathrm{Y}^{\mathrm{NTN}}$ strain and their use for strain differentiation. Plant Pathology, v. 47, p.505-509, 1998.

CLARK, M. F.; ADAMS, A. N.. Characteristics of the microplate method of Enzyme-Linked Immunosorbent Assay for detection of plant viruses. Journal of General Virology, v. 34, p. 475-83, 1977.

COOK, G.; RYBICKI, E.P.; PIETERSEN, G. Characterization of a new potyvirus isolated from peanut (Arachis hypogeae). Plant Pathology, v. 47, p. 348-354, 1998.

COYONE, C.J.; MEHLENBACHER, S.A.; HAMPTON, R.O.; PINKERTON, J.N.; JOHNSON, K.B. Use of ELISA to rapidly sceen hazelnut for resistance to eastern filbert blight. Plant Disease, v.80, n.12, p.1327-1330. 1997.

CRESCENZI, A.; d'AQUINO, L.; COMES, S.; NUZZACI, M.; PIAZZOLLA, P.; BOSCIA, D. Characterization of the sweet cherry isolate of plum pox potyvirus. Plant 'Disease, v. 81, n.7, p. 711-714. 1997.

CROWTHER, J.R. ELISA - theory and practice. Methods in Molecular Biology n. 42, 1995, 223 p.. 
CULVER, J. N.; SHERWOOD, J. L. Detection of peanut stripe virus in peanut seed by an indirect Enzyme-Linked Immunosorbent Assay using a monoclonal antibody. Plant Disease, v. 72, n. 8, p. 676-9, 1988.

DI, R.; HILL, J.H.; VAN DEUSEN, R.A. Antigenic signature analyssis reflects differences among plant virus isolates. Journal of Virology Methods, v. 42, n.2-3, p. 281-91, 1993.

DUARTE, K.M.R. Produção de anticorpos monoclonais contra o tobamovírus do mosaico do tomateiro (ToMV). Piracicaba, 1995. 84p. Dissertação (Mestrado) - Escola Superior de Agricultura "Luiz de Queiroz", Universidade de São Paulo.

DUARTE, K.M.R. Anticorpos Monoclonais aplicados à Agricultura. NAPMA, v. 2, $1996,48 \mathrm{p}$.

ESPINOZA, W. Manual de produção de tomate industrial no Vale do São Francisco. Brasília: CODEVASF, 1991, 301 p.

FERNANDES, J. J.; CARVALHO, M. G.; ALMEIDA, E. G. Distribuição do Mosaico em tomatais de duas regiões produtoras de Minas Gerais Fitopatologia Brasileira, v. 8, p.625, 1983. 
FIGUEIRA, A. R.; DOMIER L.L.; D'ARCY, C.J. Comparison of techniques for detection of barley yellow dwarf virus -PAS-IL. Plant Disease, v. 81, n. 11, p. 1236-1240. 1997.

FILLART, R.C. ; CASTELLO, J.D. Detection of tomato mosaic tobamovirus in soil from Whitemountain, New York. Phytopathology, v.86, n.11 (suppl.), p.s88, 1996.

FILLART, R.C.; BACHAND, G.D.; CASTELLO, J.D. Detection of infectious tobamoviruses in forest soils. Applied and Environmental Microbiology, v.64, n.4, p. 1430-1435, 1998.

FRENCH, C.J.; ELDER, M.; SHELTON, F. Recovering and identifying infectious plant viruses in guttation fluid. Hortscience, v.28, n.7, p.746-7, 1993.

FUJITA, M.; MISE, K.; KAJIURA Y; DOHI, K.; FURUSAWA, I. Nucleic acidbinding properties and subcellular localization of the $3^{\mathrm{a}}$ protein of brome mosaic bromovirus. Journal of General Virology, v. 79, p. 1273-1280, 1998.

GESZTESI, J.; PUCCIA, R.; TRAVASSOS, L.R.; VICENTINI, A. P.; MORAES, J.Z; FRANCO, M.F.; LOPES, J.D. Monoclonal antibodies against the 43,000 Da glycoprotein from Paracoccidioides brasiliensis modulate laminin- 
mediated fungal adhesion to epithelial cells and pathogenesis. Hybridoma, v.15, n.6, p.415- 22, 1996.

GOMES, L.H. Avaliação de quatro métodos para a caracterização de leveduras. Piracicaba, 1995. 89p. Dissertação (Mestrado) - Escola Superior de Agricultura “Luiz de Queiroz", Universidade de São Paulo.

HALK, E. L.; DE BOER, S. Monoclonal antibodies in plant-disease research. Annual Review of Phytopathology, v. 23, p. 321-50, 1985.

HAMAMOTO, H.; WATANABE, Y.; KAMADA, H.; OKADA, Y. A single amino acid substitution in the vrus-encoded replicase of tomato mosaic tobamovirus alters host specificity. Molecular Plant-Microbe Interactions,v. 10, n.8, p.1015-1018, 1997.

HARLOW, E.; LANE, D. Antibodies - a laboratory manual. $2^{\circ}$.ed., New York: Cold Spring Harbor Laboratory, 1988, 726 p.

HATAYA, T.; INOUE, A. K.; OHHSHIMA, K.; SHIKATA, E. Characterization and strain identification of a potato virus $\mathrm{Y}$ isolate non-reactive with monoclonal antibodies specific to ordinary and necrotic strains. Intervirology, v. 37 , p. $12-19,1994$. 
HOLLINGS, M.; HUTINGA, H. Tomato mosaic virus. C.M.I./A.A.B. Descriptions of Plant Viruses. No. 156, 1976.

HURN, B. A. L.; CHANTLER, S. M. Production of reagent antibodies. Methods in Enzymology, v. 70, p.104-42, 1980.

IANNELLI, D.; D’APICE, L.; COTTONE, C.; VISCARDI, M.; SCALA, F.; ZOINA, A.; DEL SORBO, G.; SPIGNO, P.; CAPPARELLI, R. Simultaneous detection of cucumber mosaic virus, tomato mosaic virus and potato virus $\mathrm{Y}$ by flow cytometry. Journal of Virological Methods, v. 69, p. 137-145, 1997.

ITURBE, R. Caracteristicas generales de la tolerancia inmunologica. Curso de Actualización "Inmunologia Aviar"pp.13-18 (Facultad de Medicina Veterinaria y Zootecnia. UNAM, 1988)

JACOBI, V.; BACHAND, G.D.; HAMELIN, R.C.; CASTELLO, J.D. Development of a multiplex immunocapture RT-PCR assay for detection and differentiation of tomato and tobacco mosaic tobamoviruses. Journal of Virological Methods, v.74, p.167-178, 1998.

JÄRVEKÜLG, L.; SÕBER, J.; SINIJÄRV, R.; TOOTS, I.; SAARMA, M. Timeresolved fluoroimmunoassay of potato virus $\mathrm{M}$ with monoclonal antibody. Annals of Applied Biology, v. 114, p. 279-91, 1989. 
JAWEE, A.; ADAMS, A.N.; RAMSDELL, D.C.; BARBA, M. Serological detection of strawberry mild yellow edge-associated virus. Acta Horticulturae, v. 385, p. 98-104, 1995.

JOELSON, T.; AKERBLOM, L.; OXELFELT, P.; STRANDBERG, B.; TOMENIUS, K.; MORRIS, T.J. Presentation of a foreign peptide on the surface of tomato bushy stunt virus. Journal of General Virology, v.78, p.1213-1217, 1997.

JOHNSTONE, A.; THORPE, R. Immunochemistry in practice. Blockwell Scient. Pub., Oxford, 1982. 298 p.

JONES, A. T.; MITCHELL, M. J.; BROWN, J. F. Infectibility of some new raspberry cultivars with arabic mosaic and raspberry ringspot viruses and further evidence for variation in British isolates of these two nepoviruses. Annals of Applied Biology, v. 115, p. 57-69, 1989.

JONES, J. B. ; STALL, R. E.; ZITTER, T. A. Compendium of Tomato Diseases, St. Paul, APS Press, 1991 75p. 
KAWAI, A.; KOBAYASHI, Y.; TSUKAMOTO, T; DAI, K; KIMURA, S.; GOTO, M. Production of monoclonal antibodies against citrus tatter leaf virus. Research Bulletin of the Plant Protection Service, v. 27, p. 55-6, 1991.

KEARNEY, J.F.; RADBRUCH, A; LIESEGANG, B.; RAJENSKY, K. A new mouse myeloma cell line that lost immunoglobulin expression but permits the construction of antibody secreting hybrid cell lines Journal of Immunology, v. 123, p. 1548-1550, 1979.

KITAJIMA, E. W. Novas abordagens na diagnose de doenças incitadas por fitoviroses. In: Congresso Brasileiro de Fitopatologia, 24, Rio de Janeiro, 1991. Resumos. Fitopatologia Brasileira, v. 16, n.2, p. 4, 1991.

KÖHLER, G.; MILSTEIN, C. Continuous cultures of fused cells secreting antibody of pre-defined specificity. Nature, v. 256, p. 495-7, 1975.

LAEMMLI, U.K. Cleavage of structural proteins during the assembly of the head of bacteriophage T4. Nature, v.227, p.680-685, 1970.

LEE, RF.; DERRICK, K.S.; McCLURE, P.; ELLIS, L.; RUCKS, P. Occurrence of severe strains of citrus tristeza virus and citrus blight in registered scion groves in the indian river. Proceedures of the Florida State Horticulture Society, v.106, p. 94-99, 1993. 
LOPES, J. L.; CARNEIRO, C. R. W. ; VILELA, A. A.; CAMARGO, E. P. Production of monoclonal antibodies against Schistosoma mansoni and trypanosomatid : a methodologycal report. Revista do Instituto de Medicina Tropical de São Paulo, v. 24, p. 327-336, 1992.

MARKHAM, R. The biochemistry of plant viruses. In: BURNET, F. M.; STANLEY, W. M.(Ed.). The viruses: biochemical, biological and biophysical properties. New York, Academic Press, 1959, v.2, cap. II, p. 33119.

MATTHEWS, R.E.F. Fundamentals of Plant Virology. Academic Press, San Diego, 1992, 403 p..

MATTHEWS, R.E.F. Diagnosis of Plant Virus Diseases. $4^{\circ}$ ed., CRC Press, 374 p., 1993.

MELO, P.C.T. Tomate. Agrianual 97: Anuário Estatístico da Agricultura Brasileira, p.402-8, 1996.

MILTON, R. C.de L.; VAN REGENMORTEL, M. H. V. Immunochemical studies in tobacco mosaic virus - III : demonstration of five antigenic regions in the protein sub-unit. Molecular Immunology, v.16, p.179-84, 1979. 
MOWAT, W.P.; DAWSON, S. Detection and identification of viruses by ELISA using crude sap extracts and unfractionated antisera. Journal of Virological Methods, v.15, p.233-47, 1987.

MURPHY, F.A.; FAUQUET, C.M.; BISHOP, D.H.L. GHABRIAL S.A. JARVIS, A.W.; MARTELLI, G.P.; MAYO, M.A.; SUMMERS, M.D. Virus Taxonomy. Sixth Report of the International Commitee on Taxonomy of Viruses. Archives of Virology, Suppl. V.10, 1995. 586p.

NAGAI, H.; COSTA, A.s. Resistência ao mosaico Y combinada com resistência ao mosaico comum, em tomateiro. Bragantia, v.31, n.1, p.1-8, 1972.

OHNO, T.; AOYAGI, M.; YAMANASHI, Y.; SAITO, H.; IKAWA, S.; MESHI, T.; OKADA, Y. Nucleotide sequence of the tobacco mosaic virus (tomato strain) genome and comparison wth the common strain genome. Journal of Biochemistry, v.96, p.1915-1923, 1984.

OI, V.T.; HERZENBERG, L.A Antibody purification: protein A-sepharose column chromatography. In: MISHELL, B.B. \& SHIIGI, S.M. Selected methods in celular immunology. San francisco, Freeman, 1980, p.368-70. 
PAPPU, H.R.; PAPPU, S.S.; KANO, T.; KOIZUMI, M.; CAMBRA, M.; MORENO, P.; SU, H.J.; GARNSEY, S.M.; LEE, R.F.; NIBLETT, C.L. Mutagenic analysis and localization of a higly conserved epitope near the amino terminal end of the citrus tristeza closterovirus capsid protein. Molecular Plant Pathology, v. 85, n. 10, p.1311-1315, 1995.

PAPPU, H.R.; PAPPU, S.S.; MANJUNATH, K.L.; LEE, R.F.; NIBLETT, C.L. Molecular characterization of a structural epitope that is largely conserved among severe isolate of plant virus. Proceedures of the National Academy of Science, USA, v. 90, p. 3641-3644, 1993.

PASQUINI, G.; BARBA, M. Production and aplication of monoclonal antibodies against apple mosaic virus. Petria, v. 1, n.1, p. 31-6, 1991.

PEREZ, R.C.M. Comparicion de tres fuentes biologicas para producir anticuerpos contra progesterona para utilizarse en radioinmunoanalisis $o$ enzimoinmunoanalisis. Cidade do Mexico, Mexico, 1991, 138 p. Tese (Doutorado) - Facultad de Medicina Veterinaria y Zootecnia, Mexico.

RAMPITSCH, C.; EASTWELL, K.C.; HALL, J. Setting confidence limits for detection of prune dwarf virus in Prunus avium with a monoclonal antibodybased triple antibody-sandwich ELISA. Annals of Applied Biology, v.126, p. 485-491, 1995. 
RAST, A.T.B. Variability of tobacco mosaic virus in relation to control of tomato mosaic in glasshouse tomato crops by resistance breeding and cross protection. Agricultural Research Reports, v.834, p.11-76, 1975.

ROITT, I.M.; BROSTOFF, J.; MALE, D.K. Imunologia. 2º ed. São Paulo, 1992.

ROUTH, G.; NGON, M.; YASSI, A.; RAO, A.L.N.; MRKOV, T.E.; DODDS, J.A. Replicaton of a wild-type and mutant clones of satellite tobacco mosac virus $n$ Nicotiana benthamiana protoplasts. Journal of General Virology, v.78, p.1271-1275, 1997.

SASAYA, T.; SHIMIZU, T.; NOZU, Y.; NISHIGUCHI, M.; INOUYE, N.; KOGANEZAWA, H. Biological, serological and molecular variabilities of clover yellow vein virus. Phytopathology, v.87, n.10, p.1014-1019, 1987.

SCARMAN, A.L.; CHN, J.C.; EAMENS, G.J.; DELANEY, S.F.; DJORDJEVIC, S.P. Identification of novel species-specific antigens of Mycoplasma hyopneumniae by preparative SDS-PAGE ELISA profilng. Microbiology, $v$. 143, p.663-673, 1997.

SCHECHTER, G. B.; LOPES, J. D. Two-site immunoassays for the measurament of serum laminin: correlation with breast cancer staging and presence of auto- 
antibodies. Brazilian Journal of Medical and Biological Research, v.23, p. 141-149, 1990.

SCHIEBER, O.; SEDDAS, A.; BELIN, C.; WALTER, B. Monoclonal antibodies for detection, serological characterization and immunopurification of grapevine fleck virus. European Journal of Plant Pathology, v.103, p.767-774, 1997.

SCHOEN, C.D.; KNORR, D.; LEONE, G. Detection of potato leafroll virus in dormant potato tubers by immunocapture and a fluorogenic 5'nuclease RTPCR assay. Phytopathology, v.86, n.9, p.993-999, 1996.

SCHOTS, A.; GRIEP, R.; BAKKER, J.; SKERRITT, J.H.; APPELS, R Monoclonal antibody technology.- New diagnostics in crop sciences. Biotechnology in Agriculture, v. 13, p.65-86, 1995.

SCHUERGER, A. C.; BROWN C.S. Spectral quality affects disease development of three pathogens on hydroponically grown plants. Hortscience, v.32, n.1, p.96-100, 1997.

SEQUEIRA, J. C. Técnicas serológicas e bio-moleculares de diagnóstico de vírus e viróides em plantas. Summa Phytopathologica, v.18, n.2, p. 79-110, 1992. 
SHERWOOD, J. L.; SANBORN, M. R.; KEYSER, G. C.; MYERS, L. D. Use of monoclonal antibodies in detection of tomato spotted wilt virus. Phytopathology, v.79, n.1, p. 61-4, 1989.

SHULMAN, M.; WILDE, C. D.; KÖHLER, G. A better line for making hybridomas secreting specific antibodies. Nature, v. 276, p.269-270, 1985.

ST. GROTH, S. F.de; SCHEIDEGGER, D. Production of monoclonal antibodies: strategies and tatics. Journal of Immunological Methods, v.35, p. 1-21, 1980.

SUTULA, C.L.; GILLETT, J.M.; MORRISSEY, S.M.; RAMSDELL, D.C. Interpreting ELISA data and establishing the positive-negative threshold. Plant Disease, v.70, n.8, p.722-6, 1986.

SWANSON, M.M.; HARRISON, B.D. Serological relationships and epitope profiles of isolates of okra leaf curl geminivirus from Africa and Middle East. Biochemie, v. 75, n.8, p. 707-11, 1993.

SWANSON, M.M; VALAND, G.B.; MUNIYAPPA, V.; HARRISON, B.D. Serological detection and antigenic variation of two whitefly-transmited geminiviruses: tobacco leaf curl and croton yellow vein mosaic viruses. Annals of Applied Biology, v.132, p.427-435, 1998. 
THOMAS, J.E.; DIETZGEN, R.G. Purification, characterization and serological detection of virus-like particles associated with banana bunchy top disease in Australia. Journal of General Virology, v. 2, n. PT2, p. 217-24, 1991.

TRIONE, E. J. The use of monoclonal antibodies in plant pathology. In: HESS, W. M.; SINGH, R. S.; SINGH, U. S.; WEBER, D. J. Experimental and conceptual plant pathology. 1988. Gordon \& Buach Science Publ., New York, cap. 2, 33-43.

VAN REGENMORTEL, M. H. V. Serology and immunochemistry of plant viruses. New York, Academic Press, 1982. 302p.

VAN REGENMORTEL, M. H. V.; LEGARGE, N. The antigenic specificity of different states of agregation of tobacco mosaic virus protein. Virology, v. 52, p. 89-104, 1973.

VOLLER, A.; BARTLETT, A.; BIDWELL, D. E.; CLARK, M. F.; ADAMS, A. N. The detection of viruses by Enzyme-Linked Immunosorbent Assay (ELISA). Journal of General Virology, v. 33, p. 165-7, 1976.

WEBER, H. ; PFITZNER, J.P. Tm- $2^{2}$ resistance in tomato requires recognition of the carboxy terminus of the movement protein of tomato mosaic vinus. Molecular Plant-Mocrobe Interaction, v.11, n.6, p. 498-503, 1998. 
ZAITILIN, M.; ISRAEL, H.M. Tobacco Mosaic Virus (type strain). In:

Descriptions of Plant Viruses, Kew, Surrey Commonwealth Mycological Institute, 1975, v. 151, 5p.

ZHANG, H.B.; ZHU, X.R.; LIU, W.; ZHANG, Y.K. The detection of banana bunchy top disease with monoclonal antibody of BBTV. Acta Phytophylacica Sinica, v. 22, n. 1, p. 75-79, 1995. 